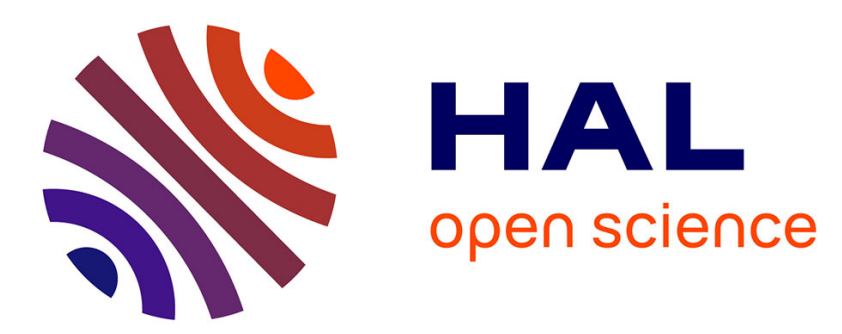

\title{
Fatty acids associated with the frustules of diatoms and their fate during degradation - A case study in Thalassiosira weissflogii
}

Maxime Suroy, Brivaëla Moriceau, Julia Boutorh, Madeleine Goutx

\section{- To cite this version:}

Maxime Suroy, Brivaëla Moriceau, Julia Boutorh, Madeleine Goutx. Fatty acids associated with the frustules of diatoms and their fate during degradation - A case study in Thalassiosira weissflogii. Deep Sea Research Part I: Oceanographic Research Papers, 2014, 86, pp.21-31. 10.1016/j.dsr.2014.01.001 . hal-01073211

\section{HAL Id: hal-01073211 \\ https://hal.science/hal-01073211}

Submitted on 9 Oct 2014

HAL is a multi-disciplinary open access archive for the deposit and dissemination of scientific research documents, whether they are published or not. The documents may come from teaching and research institutions in France or abroad, or from public or private research centers.
L'archive ouverte pluridisciplinaire HAL, est destinée au dépôt et à la diffusion de documents scientifiques de niveau recherche, publiés ou non, émanant des établissements d'enseignement et de recherche français ou étrangers, des laboratoires publics ou privés. 
2 degradation - a case study in Thalassiosira weissflogii.

${ }^{1}$ Aix-Marseille Université, Université du Sud Toulon-Var, CNRS/INSU, IRD,

Mediterranean Institute of Oceanography (MIO), UM 110, 13288, Marseille, Cedex 09, France.

${ }^{2}$ Université de Brest, Institut Universitaire Européen de la Mer (IUEM), CNRS,

Laboratoire des Sciences de l'Environnement Marin, UMR

\section{Abstract:}

Diatoms are major actors in the export of organic carbon out of the euphotic zone. Yet, the processes linking biogenic silica and carbon sedimentation fluxes to deep oceanic layers remain unclear. Analysing organic fractions in biominerals is challenging because efficient cleaning often led to structural alteration of organic molecules. Hence, although lipids are widely used as biogeochemical markers in ocean flux study, few studies have dealt with the lipids that are associated with frustules. In the present study, a protocol was set up to extract and quantify the fatty acids associated to the frustule of the diatom species Thalassiosira weissflogii. The protocol involves solvent extraction of diatom external lipids, followed by clean frustule dissolution by $4 \% \mathrm{NaOH}$ during $1 \mathrm{~h}$ at $95^{\circ} \mathrm{C}$ and subsequent solvent reextraction of frustule-associated lipids. Results confirmed that this protocol was efficient first, to isolate the frustule from the rest of the cellular organic carbon and second to extract and quantify fatty acids (FA) associated to frustules of this species. FA composition of the frustules was significantly different from that of the whole cells consisting primarily of 14:0, 
$2616: 0$ and 18:0 FA, as well as a smaller portion of 16:1 and 18:1 unsaturated FA. Frustule-

27 associated FA constituted $7 \%$ of the total FA and $1.8 \%$ of the total POC. The 30 days $T$.

28 weissflogii degradation/dissolution experiment suggested that frustule FA 14:0 and 16:0 were

29 mainly associated with the $\mathrm{bSiO}_{2}$ phase dissolving slowly as no degradation of this pool was

30 measured despite $78 \%$ frustule dissolution. At the end of the degradation experiment, this

31 pool constituted $5.8 \%$ of the remaining total POC suggesting an effective protection by the

32 frustule through strong interaction with the organic matrix which is consistent with the

33 correlation observed at depth between Si and POC sedimentation fluxes.

34

35 Keywords: Frustule, Diatoms, Organic Carbon, Lipids, Carbon Export

36 


\section{Introduction}

Diatoms are characterised by a silicified cell wall, commonly known as the frustule. This frustule partially consists of amorphous silica that forms mineral structures by precipitation of orthosilicic acid (Martin-Jézéquel et al., 2000). Such a structure presents great evolutionary advantages to cells, such as turgor resistance and protection against predation (Raven and Waite, 2004 and reference therein), or optical properties (Kucki, 2009), partially explaining the success of diatoms and the presumed number of diatom species (more than 200 000, Mann and Droop, 1996). This success is illustrated by diatom's predominant role in primary production in the ocean (Falkowski et al., 1998) but also in the export of organic matter (OM) to the ocean depths (Nelson et al., 1995; Volk and Hoffert, 1985). Diatom frustule-bound organic compounds are diverse. The formation of the frustule starts within silicon deposition vesicles and requires a peculiar association between organic compounds and silicon (Hildebrand, 2008). Many studies have demonstrated the role of proteins and polyamines during the precipitation of silica in diatoms (Brunner et al., 2009). The presence of sugars closely associated with frustule is also confirmed in recent studies, but their role in the biomineralisation process remains unclear (Chiovitti et al., 2005; Tesson and Hildebrand, 2013). In contrast, because they are not assumed to be functionally critical to the formation of the biogenic silica, little is known about the potential association of lipids in frustules. Diatoms (Fileman et al., 1998) and frustule-bound organic compounds (Bridoux and Ingalls, 2010; Bridoux et al., 2012; Hedges et al., 2001; Ingalls et al., 2010) provide organic matter to the sediment. Compilation of deep sedimentation fluxes of POC and minerals (Armstrong et al., 2002; Buesseler, 1998; De La Rocha and Passow, 2007) show correlations between those fluxes. More specifically, deep sedimentation fluxes of particulate organic carbon (POC) and biogenic silica $\left(\mathrm{bSiO}_{2}\right)$ are also correlated when expressed basin by basin (Ragueneau et al., 2006). Using an independent data base, Ragueneau and co-workers (2002) 
showed that the evolution of the $\mathrm{Si} / \mathrm{C}$ in all areas of the ocean can be predicted using an empirical relationship. In other words, the sinking of $\mathrm{bSiO}_{2}$ and $\mathrm{POC}$ are linked in such a manner that knowing $\mathrm{Si} / \mathrm{C}$ in the surface layer, one can theoretically extrapolate the flux of POC from the flux of $\mathrm{bSiO}_{2}$. But what processes could explain such a link between the preserved fraction of organic matter and the $\mathrm{bSiO}_{2}$ ?

The preservation of a fraction of organic matter during the sedimentation through the water column to the sediment depends on the balance between sinking and degradation processes. Biominerals in general and $\mathrm{bSiO}_{2}$ in particular could impact both processes. As suggested by the ballast ratio hypothesis (Armstrong et al., 2009, 2002; Klaas and Archer, 2002), the sinking of organic matter ballasted by dense biominerals be it as shells or once incorporated to the same large particles like aggregates or fecal pellets (Thornton, 2002; Turner, 2002) should be faster than the sinking of non-ballasted organic matter. Moreover $\mathrm{bSiO}_{2}$ may also slow down the degradation as some studies hypothesized that the diatom frustule surrounding the cellular organic matter could protect the internal pool against bacterial degradation (Goutx et al., 2007; Moriceau et al., 2009). But these studies were undertaken on living diatoms and this hypothesis is not confirmed by degradation studies made on dead diatoms (Soler et al., 2010).

Other studies have evidenced the presence of another organic pool intimately linked to the frustule that could potentially explain the correlation between organic carbon and $\mathrm{bSiO}_{2}$. This fraction of organic matter preserved at great depths is proportional to the flux of biominerals (Armstrong et al., 2009, 2002; François et al., 2002; Klaas and Archer, 2002; Ragueneau et al., 2006, 2002). In our study, we hypothesized that the preserved organic matter can be partially formed by the pool of lipids associated to or embedded in the silica matrix. 
The presence of an organic coating has been so far mainly deduced from $\mathrm{bSiO}_{2}$ dissolution experiments on whole versus cleaned frustule (Bidle and Azam, 1999; Kamatani and Riley, 1979; Patrick and Holding, 1985). From the experimental results described in the study by Bidle and Azam (1999), it seems that this pool is removed by bacteria within hours or few days after the death of diatoms. Only few diatoms can reach the sediment with an intact organic coating as shown by a minimum of $50 \%$ dissolution of the $\mathrm{bSiO}_{2}$ observed in most oceanic sites. The frustule-embedded OM is more difficult to assess as the chemical reagents known to dissolve the silica $\left(\mathrm{NaOH}, \mathrm{Na}_{2} \mathrm{CO}_{3}\right.$ and $\left.\mathrm{HF}\right)$ generally react with the targeted polymer organic compounds. The inclusion of proteins in the silica matrix and their implication in silicification have been well-investigated (Hildebrand, 2003; Hildebrand et al., 2009; Kröger et al., 2002, 1999, 1997, 1994). The presence of other molecules less directly involved on silicification processes, such as lipids or sugars, has been much less studied. Kates and Volcani (1968) described the lipid composition of the cell wall for the first time after breaking and washing the cells. To our knowledge, this study remains the only one dealing at the molecular level with lipids associated to diatom frustules. Recent works studied this organosilicon structure and noted the importance of lipid-like compounds embedded in the frustule of diatoms using spectroscopic methods (Soler et al., 2010; Tesson et al., 2008). These global methods that avoid dissolution procedures and the potential denaturation of most organic molecules, confirm the presence of $\mathrm{OM}$ associated with the frustule but did not reveal details about the structure and amounts of the classes of compounds detected.

In the present work, our approach combined the procedures of Ragueneau and Tréguer (1994) and Chiovitti et al. (2005) and enabled the complete dissolution of the frustules and the study of released FA. The protocol was developed on the diatom Thalassiosira weissflogii and a 30-day dissolution/degradation experiment was carried out first to validate our protocol and second to understand the fate of frustule-associated lipids during biodegradation. 


\section{Material and Methods}

\subsection{Culture conditions and sampling}

The strain Thalassiosira weissflogii (CCMP $\left.{ }^{\circ} 1049\right)$ was provided by the National Centre for Marine Algae and Microbiota. Three cultures (A, B and C cultures) were grown in $\mathrm{f} / 2$ medium under a $14 / 10 \mathrm{~h}$ light/dark cycle at $18^{\circ} \mathrm{C}$ in 21 glass flasks (Guillard and Ryther, 1962) in sterile conditions. Culture $\mathrm{C}$ was grown in another growth chamber under similar growth conditions (temperature, light intensity and cycles). Differences in the carbon content of cultured cells were observed $\left(15.6 \pm 0.2,15.6 \pm 0.1\right.$ and $10.9 \pm 0.1$ pmol.cell $^{-1}$ in cultures
A, B and C, respectively). The cell concentration was determined by flow cytometry (FACS Calibur, BD biosciences $\left.{ }^{\circledR}\right)$.

Samples were collected as soon as cultures reached the stationary phase $\left(\sim 10^{5}\right.$ cell.ml ${ }^{-1}$ and 15 days of growth). Triplicate of $10 \mathrm{ml}$ of culture were sampled in cultures B and C for the 'whole cells' analysis and filtered on pre-combusted GF/F filters $(0.7-\mu \mathrm{m}$ mesh size) as generally done in other studies (Table 1). Lipids from whole cells were extracted according to the Bligh and Dyer protocol (1959) and thus do not include the frustule-associated fraction. Culture A was not sampled for lipid composition analysis in whole cells. The carbon content of cells in batch A was similar to that of cells in batch B, suggesting composition similarity between A and B cultures. Except the 20:5(n-3) FA (see Fig. 4 below), this latter assumption was supported by the low SD of average percentages of individual FA in total FA, derived from the analysis of FA in triplicate samples from both $\mathrm{B}$ and $\mathrm{C}$ cultures. To obtain the 'pellet' samples, triplicates of $50 \mathrm{ml}$ of the three cultures were centrifuged at $5400 \mathrm{~g}$ (20 min).

\subsection{Frustule isolation}

Pellet samples were resuspended in $40 \mathrm{ml}$ milli $Q$ water and were hot-sonicated at 70 ${ }^{\circ} \mathrm{C}$ for $5 \mathrm{~min}$ to fragment the cells (Fig. 1). Tubes were subsequently centrifuged at $5400 \mathrm{~g}$ for $40 \mathrm{~min}$ at $4{ }^{\circ} \mathrm{C}$. The supernatants were removed, and this step was repeated once at lower 
centrifugation speed (3800 $\mathrm{g}$ for $20 \mathrm{~min}$ ) to eliminate any non-frustule material. After removing the supernatant, the pellets were again resuspended in $40 \mathrm{ml}$ milli $Q$ water and centrifuged at $3200 \mathrm{~g}$ for $20 \mathrm{~min}$. This treatment cleared the frustules from most cell content. However, fluorescence of chlorophyll molecules was noticeable on flow cytometer analysis of the washed pellets indicating external organic material still present on frustule fragments (Fig.2).

In a second step, this external organic material probably more intimately linked to the frustules than the previous cell content, was separated from fragmented frustules using a modified protocol of Bligh and Dyer. Briefly, the washed pellets were transferred to glass tubes. A monophasic mixture of dichloromethane/methanol/1M salt water $(1 / 2 / 0.8, \mathrm{v} / \mathrm{v} / \mathrm{v})(9.5$ ml) was added for the lipid extraction. After the addition of an internal standard (nonadecanoic acid methyl ester, Me19:0, Sigma Aldrich $\left.{ }^{\circledR}\right)$ and sonication (10 min), tube contents were transferred to separatory funnels. Tubes were rinsed with $9.5 \mathrm{ml}$ of the monophasic mixture. The separatory funnel contents were made biphasic by adding $5 \mathrm{ml}$ dichloromethane (DCM) and $5 \mathrm{ml}$ milli $Q$ water. After vigorous shaking and settling, the organic phases were collected, and the aqueous phases were re-extracted with $10 \mathrm{ml}$ DCM.

The organic phases were combined and concentrated under a gentle flux of nitrogen. The lipid extracts such obtained from the pellets of isolated frustules constituted our lipid 'external' fractions.

\subsection{Extraction of frustule-associated lipids}

Frustules cleaned from their 'external' fraction were visualised by scanning electronic microscopy during the cleaning procedure to check for their integrity and the absence of 'external' organic matter at the end of this step. Frustule fragments formed a white layer at the basis of the aqueous phase (methanol/water mixture) remaining in the separatory funnel after the Bligh and Dyer extraction (Fig. 1). Scanning electron microscopy analysis of this white 
161 layer samples showed an amalgam of clean silica frustules (Fig. 3). Hydrophilic compounds

162 that may be present in the aqueous phase were not analysed further. The white layer and the top aqueous phase were transferred into glass bottle in which sodium hydroxide $\left(1 \mathrm{mol.1}{ }^{-1}\right.$

164 final concentration) was added. These bottles were later transferred to a water bath at $95{ }^{\circ} \mathrm{C}$

165 for $1 \mathrm{~h}$ to promote the entire dissolution of frustules. The basic reactant not only dissolves the

166 silica matrix but can cleave covalent associations between FA and polymers. After a rapid

167 cooling on ice, the bottle contents were acidified using $\mathrm{HCl}$ and re-extracted in a liquid-liquid 168 phase using $50 \mathrm{ml} \mathrm{DCM}$ (the aqueous phase was approximately $70 \mathrm{ml}$ ). This last extraction

169 step was repeated three times to ensure the complete extraction of the remaining lipids in the

170 aqueous phase. Extracts thus obtained were called the 'frustule-associated' fractions. The

171 internal standard (Me19:0) was not added before dissolved frustule extraction in order to

172 control the absence of contamination in the 'frustule-associated' extract from the 'external'

173 fraction. Consequently, the same extraction recovery was used for the quantification of both

174 'external' and 'frustule-associated' lipids.

175

176

177

178

179

180

181

182

183

184

185

\subsection{Biodegradation experiment}

For the degradation experiment, the $T$. weissflogii strain was supplied and grown in a large volume culture by the Experimental Station of Argenton (Ifremer, France). Cells were pelleted and killed by freezing at $-20^{\circ} \mathrm{C}$ for 4 days. Pellets were resuspended in a Nalgene ${ }^{\circledR}$ flask filled with 101 of $0.7-\mu \mathrm{m}$ filtered seawater from Brest Bay (France). The 0.7- $\mu \mathrm{m}$ filtered water contained the natural prokaryotic community required to degrade and utilize the algal material as growth substrate. The flask was incubated on an orbital shaker table at $70 \mathrm{rpm}$ in

the dark at $18{ }^{\circ} \mathrm{C}$. The degradation experiment lasted 30 days. Samples $(50 \mathrm{ml})$ were collected from the flask every 6 days, in duplicate or triplicate, and subjected to centrifugation for frustule isolation and lipid extraction as described in the previous section. Briefly, cells were sonicated, pelleted to remove medium and extracted according to Bligh and Dyer for analysis 
of external FA composition. Cleaned frustules were submitted to $\mathrm{NaOH}$ dissolution and re-

187 extracted for analysis of frustule-associated FA fraction.

\subsection{Bulk parameters: $\mathrm{bSiO}_{2}, \mathrm{POC}$ and prokaryotic concentrations} $\mathrm{bSiO}_{2}$ and $\mathrm{POC}$ concentrations were followed during the whole degradation experiment by filtering $10 \mathrm{ml}$ of the batch content on polycarbonate $(0.4-\mu \mathrm{m}$ mesh size $)$ and GF/F (0.7- $\mu \mathrm{m}$ mesh size) filters, respectively. $\mathrm{bSiO}_{2}$ concentrations were measured using a variation of the method of Ragueneau and Tréguer (1994) described in Moriceau et al. (2009). Filters were digested in $20 \mathrm{~mL}$ of 0.2 $\mathrm{M} \mathrm{NaOH}$ for 3 hours at $95^{\circ} \mathrm{C}$ and stirred regularly to ensure the dissolution of all $\mathrm{bSiO}_{2}$. As no lithogenic silica was present in the diatom culture, only one longer digestion step was done. The solution was then acidified with $5 \mathrm{~mL}$ of $\mathrm{HCl} 1 \mathrm{M}$, centrifuged to remove solids and analysed for silicic acid concentrations (dSi). dSi was measured using the molybdate blue spectrophotometric method of Mullin and Riley (1955), as adapted by Tréguer and Le Corre, (1975) and modified by Gordon et al. (1993) for use in segmented flow colorimetry. We used a Bran and Luebbe Technicon Autoanalyser ( $<1 \%$ precision).POC filters were desiccated overnight in an oven at $50{ }^{\circ} \mathrm{C}$, and POC was quantified by using a Carlo Erba NA $2100 \mathrm{CN}$ analyser coupled to a Finnigan Delta S mass spectrometer.

Prokaryotes were counted over time in $10 \mathrm{ml}$ samples to assess their growth. Free and attached prokaryotes were separated by filtration ( $3-\mu \mathrm{m}$ mesh size $)$ and counted on black $0.2-$ $\mu \mathrm{m}$ filters after staining with DAPI (4',6-diamidino-2-phenylindole).

Prokaryotic carbon in degradation flask samples was calculated by using conversion factors (20 and $50 \times 10^{-15}$ molC.cell $^{-1}$ for free and attached prokaryotes, respectively) according to Turley and Mackie (1994) for the north-eastern Atlantic Ocean. 


\subsection{Lipid analysis}

\subsubsection{Derivatisation and purification.}

Lipid extracts were trans-esterified using $\mathrm{BF}_{3}$-Methanol and toluene for $1 \mathrm{~h}$ at $70{ }^{\circ} \mathrm{C}$. Fatty acid methyl esters (FAME) were extracted from the mixture with $3 \times 2 \mathrm{ml}$ of Hexane/Ethyl Ether (98/2, v/v) and evaporated to dryness under nitrogen. FAME were purified onto a bond elute microcolumn with a mix of Hexane-Ethylacetate (99/1, v/v).

Columns were conditioned with $9 \mathrm{ml}$ Hexane-Ethyl Acetate (99/1, v/v) followed by $3 \mathrm{ml}$ Hexane. Columns were rinsed with $1.4 \mathrm{ml}$ Hexane (to remove hydrocarbons), and FAMEs were eluted by $1.6 \mathrm{ml}$ Hexane-Ethyl Acetate (99/1, v/v).

Extracts from the degradation experiment were first saponified (KOH 1 mol. ${ }^{-1}$ for $1 \mathrm{~h}$ at $70{ }^{\circ} \mathrm{C}$ ) and were silylated using a N,O-bis(trimethysilyl)trifluoroacetamide (BSTFA)pyridine mixture according to Rontani et al. (2011). Briefly, after saponification, BSTFA and pyridine were added to the dried lipid extract $(1 / 2, \mathrm{v} / \mathrm{v})$. Tubes were placed at $50^{\circ} \mathrm{C}$ for $1 \mathrm{~h}$, and then their contents were dried under a gentle stream of nitrogen and resuspended in ethyl acetate and BSTFA. This reaction transforms $\mathrm{OH}$-containing molecules to their trimethylsilyl (TMS) derivatives. Injections of trimethylsilyl ether (TMSE) were made in the $12 \mathrm{hrs}$ following derivatisation due to their unstable nature. This method allowed us to analyse FA, sterols and phytol simultaneously in their TMS ether forms. Indeed, the phytil side chain of chlorophyll is released during saponification (phytol) and transformed to its TMS derivative. Sterols are also present in diatoms, primarily in a free form (i.e., non-esterified, Volkman and Hallegraeff, 1988). Four sterols (Volkman and Hallegraeff, 1988) were identified, but we combined them in this study. Sterols were quantified by reference to a calibration curve of a cholesterol standard. The quantification of phytol was semi-quantitative using a calibration curve of TMS20:0. 
The impact on PUFA of the step involving heating the silica/organic matter complex

234 was tested. The percentage recoveries of arachidonic acid (20:4(n-6)) after incubation for one

235 hour both at $40{ }^{\circ} \mathrm{C}$ and $70{ }^{\circ} \mathrm{C}$ were in the range of the RSD. Other authors also reported

236 saponification of lipid extracts at $100{ }^{\circ} \mathrm{C}$ without noticeable effect on poly-unsaturated FA

237 quantification (Chen et al., 2011; Goutx et al., 2007).

\subsubsection{GC/MS analysis.}

FAME and TMSE were analysed by gas chromatography/mass spectrometer (GC/MS)

240 (TraceISQ, ThermoElectron) at an ionization energy of $70 \mathrm{eV}$ for $\mathrm{m} / \mathrm{z}$ range of $50-400$ for

241 FAME and 50-600 for TMSE, using hydrogen as carrier gas at a flow rate of $1.2 \mathrm{ml} . \mathrm{min}^{-1}$.

242 The injector (used in splitless mode) and detector temperatures were 250 and $320^{\circ} \mathrm{C}$

243 respectively. For FAME analysis, the initial column temperature was held for 2 min at $70{ }^{\circ} \mathrm{C}$

244 then ramped at $12{ }^{\circ} \mathrm{C} \cdot \mathrm{min}^{-1}$ (ramp 1) to $140{ }^{\circ} \mathrm{C}$, and then at $5^{\circ} \mathrm{C} \cdot \mathrm{min}^{-1}$ (ramp 2) to $200{ }^{\circ} \mathrm{C}$,

245 which was held for $5 \mathrm{~min}$, then finally ramped at $12{ }^{\circ} \mathrm{C} \cdot \mathrm{min}^{-1}$ (ramp 3) to $275^{\circ} \mathrm{C}$ and held for

$24610 \mathrm{~min}$. FA, sterols and phytol from the degradation experiment were analysed in their TMS

247 forms using the same conditions as FAME analysis on the same GC/MS. The ramp

248 temperature only was modified as follow: the initial temperature was set at $70{ }^{\circ} \mathrm{C}$ and

249 successively increased to $130{ }^{\circ} \mathrm{C}$ at $20^{\circ} \mathrm{C} \cdot \mathrm{min}^{-1}$, then to $250{ }^{\circ} \mathrm{C}$ at $5{ }^{\circ} \mathrm{C} \cdot \mathrm{min}^{-1}$ and finally at 3

$250{ }^{\circ} \mathrm{C} \cdot \mathrm{min}^{-1}$ to $300{ }^{\circ} \mathrm{C}$, held for $40 \mathrm{~min}$. The source temperature was set at $200{ }^{\circ} \mathrm{C}$. FAME and

251 TMSE were identified by comparison with retention time and mass spectra of commercial

252 standards (provided by Sigma Aldrich ${ }^{\circledR}$ ) and quantified by reference to calibration curves.

253 The positions of the double bounds were all identified with the exception of that of $16: 1,16: 2$

254 and 24:1 for which we did not run standards. All determination coefficients were up to 0.99 .

255 Tricosanoic acid methyl ester standard (Me23:0) was introduced prior to injection to check

256 analytical variability. The mean analytical recovery, taking into account all preparative steps

257 except dissolution, was in the range of the Relative Standard Deviation (4 to $9 \%$ for peak 
areas and from 0.04 to $0.11 \%$ for the retention time) and was approximately $83 \%$. As we did not add any standard to the frustule-bound fraction, internal standard (19:0 in its trimethylsilyl or methyl form) was used to check whether any cellular material (that contained the internal standard) may have contaminated the 'frustule-bound' fraction. All concentration values were blank and recovery corrected.

\subsection{Flow cytometry.}

Samples were analysed using the FACSCalibur (BD Biosciences ${ }^{\circledR}$ ) of the PRECYM flow cytometry platform (http://precym.com.univ-mrs.fr) equipped with a blue (488 $\mathrm{nm})$ aircooled argon laser and a red $(634 \mathrm{~nm})$ diode laser. Data were collected using the CellQuest software (BD Biosciences ${ }^{\circledR}$ ). The analysis was performed a posteriori using SUMMIT v4.3 software (Beckman Coulter). T. weissflogii cells were optically resolved based on their intensities in light scatter and red fluorescence (chlorophyll $a$ related). TruCount beads (BD Biosciences ${ }^{\circledR}$ ) and 2- $\mu \mathrm{m}$ beads (Fluoresbrite YG, Polyscience ${ }^{\circledR}$ ) were added to the samples as an internal standard to monitor the instrument stability and to determine the volume analysed by the instrument. Flow cytometry analysis was used to test frustule isolation and to measure prokaryotic presence in samples without additional prokaryotic counting.

\subsection{Statistical analysis.}

All analyses were performed with R (R Core Team, 2012), a freeware for statistical analysis available at http://cran.r-project.org/. A Mann-Whitney $U$ test was also used to test the hypothesis $\mathrm{H}_{0}$ that there is no difference between FA concentration averages during the degradation experiment. We fixed the significance level at $5 \%$.

To compare the FA profiles of 'whole cells', 'extrenal' and 'frustule-associated' fractions, a classical multidimensional scaling (MDS) was used on an Euclidean distance matrix of FA standardised concentrations. Using k-means clustering, we partitioned our samples into three groups. The number of clusters in this analysis must be defined by the 
283

284

analyst. We choose three clusters because we have three sample types and also because it was the result of the estimation by optimum average silhouette width using the fpc package in the R software (Christian, 2010). Confident ellipses at 50 and $95 \%$ were added to the plot to represent results from cluster analysis and to comfort MDS observations.

\section{Results}

\subsection{FA composition of Thalassiosira weissflogii}

Whole cells (WC) fractions from two different cultures (B and C) had similar FA compositions. The average composition $(n=6)$ was also similar to literature data on the same genus (Table 1) and did not show obvious differences despite various methodologies used in previous studies (Table 1). The composition of WC was dominated by palmitic acid 16:0 $(26.4 \pm 3.4 \%, \mathrm{n}=6)$ (Table 1). The other dominant FA were those classically found in diatoms: palmitoleic acid (16:1(n-7)) and eicosapentaenoic acid (20:5(n-3) or EPA) (18.3 \pm $4.3 \%$ and $22.5 \pm 9.6 \%$, respectively). A characteristic feature was the dominance of $16-$ carbon atom unsaturated FA compared to 18-carbon atom unsaturated FA (38.0 \% versus 2.7 $\%$, respectively) (Table 1). Also, 20:0 and 22:0 saturated FA were found in notably low amounts (their sum was $<0.5 \%$ ), but their presence was confirmed by the analysis of their mass spectra. Traces of heptadecanoic acid (17:0) and pentadecenoic acid (15:1) represented less than $0.1 \%$ of the total FA in WC. Those FA are generally attributed to prokaryotes (Kaneda, 1991). Considering their low contribution to the total composition, the share of these FA most likely reflected the presence of few bacteria. This scarcity was confirmed by flow cytometry, which showed notably few microorganisms other than diatoms in the cultures (Fig. 2). Therefore, we did not take these bacterial markers into account in the FA profile of $T$. weissflogii. 
The 'external' fractions showed of the three cultures (A, B, and C), as for whole cells, 308 a dominance of 16:0, 16:1(n-7) and 20:5(n-3) FA $(18.0 \pm 4.4 \%, 18.2 \pm 3.2 \%$ and $28.6 \pm 6.8$ $309 \%$, respectively, $\mathrm{n}=9$ ) (Fig. 4). Taking into account the 16:2 and 16:3(n-4) FA, these FA 310 represented more than $85.9 \%$ of the total FA for both WC and 'external' fractions.

The 'frustule-associated' fraction was dominated by saturated 14:0 and 16:0 FA (17.3

$312 \pm 5.9 \%$ and $57.0 \pm 4.9 \%$, respectively) (Fig. 4). This predominance of saturated FA led to a

313 lower contribution of other FA. Contrarily to the WC and 'external' fraction, unsaturated FA

314 with 16-carbon atoms were much less abundant in frustule-associated fraction $(38.0 \%, 41 \%$

315 and $10.8 \%$ in WC, 'external' and 'frustule-associated' fractions, respectively) (Fig. 4).

316 Moreover, no branched nor 17:0 FA prokaryote markers were found in these fractions

317 emphasizing the non-contamination of 'frustule-associated' fraction. The major difference

318 with FA composition of the whole cell was the low degree of unsaturation of the FA from the 319 frustule.

320 Using k-means clustering method and MDS, comparison of FA profiles enabled to 321 identify three "groups": WC and 'external' fractions from culture A and B on the one hand, 322 WC and 'external' fractions from culture $\mathrm{C}$ on the other hand, and a third group composed of 323 'frustule-associated' fractions from all cultures (Fig. 5). The fact that A, B and C 'frustuleassociated' fractions were gathered together emphasized the specificity of frustule FA profiles 325 regardless of the culture conditions. The difference between culture $\mathrm{C}$ and the two other 326 cultures may be explained by a higher contribution and variability of 20:5(n-3) FA in culture 327 C in both 'external' and whole cells samples (Fig. 4), which were most probably related to the 328 different growth chamber (see section 2.1) or to a lag time for the sampling regarding the 329 growth curve. 
Diatom material for the degradation experiment was obtained from the continuous

reactor culture from Argenton. The overall degradation of the diatom material was reflected in

333 the decrease of both $\mathrm{POC}$ and $\mathrm{bSiO}_{2}$ concentrations over the 30-day incubation period (from 1480.2 to $496.6 \pm 14.5 \mu \mathrm{mol} . \mathrm{l}^{-1}$ and from $342.9 \mu \mathrm{mol}^{-1} \mathrm{I}^{-1}$ to $76.4 \pm 2.4 \mu \mathrm{mol} . \mathrm{l}^{-1}$ for POC and $\mathrm{bSiO}_{2}$, respectively) (Fig. 6). As expected, prokaryotes largely contributed to diatom decomposition, as shown by the increase in prokaryotic carbon during the first 4 days (Fig. 6). A total of $22 \%$ of the initial $\mathrm{bSiO}_{2}$ still remained in the batch at the end of the incubation experiment.

During the course of the degradation experiment, we focused on the kinetics of 'frustule-associated' FA and compared them with the kinetics of external lipids to highlight 341 differences in degradation trends of the two fractions. External phytol and sterols represented $10.5 \pm 3.2 \%$ of the total external lipid pool $(\mathrm{FA}+$ Sterols + Phytol $)$ at day 0 . Their decrease over time from $17.7 \pm 5.9 \mu \mathrm{mol} \mathrm{C} .1^{-1}$ to below the detection limit at day 18 for phytol and

344 from $18.0 \pm 6.3 \mu \mathrm{mol} \mathrm{C} .1^{-1}$ to $5.6 \pm 0.8 \mu \mathrm{molC} .1^{-1}$ for sterols, well reflected the degradation of 345 external algal material (Fig. 7). Total sterol concentrations exhibited an increase at day 6, 346 mainly because of the analytical variability that was quite high between replicates, for the 24methylene cholesterol in particular. We were not able to attribute this increase to any process.

348 Interestingly, neither phytol nor sterols were detected in the 'frustule-associated' fraction.

349 This observation and the fact that the internal standard (19:0) added to the pellet extraction

350 medium has never been found in the 'frustule-associated' fraction confirmed that our protocol 351 accurately separated these two fractions. The saturated FA proportion (especially 18:0) of the 'external' fraction during 353 degradation was higher than in cultures used to set up the protocol. Several factors may 354 increase saturated FA in pellets. The culture used for degradation was more mature than 
culture used to set up the protocol and proportions of unsaturated FA more susceptible to

356 oxidative attack than saturated ones, decrease in mature cells. Moreover, prokaryotes enriched

357 in saturated FA, were present in the culture medium at initial time of the degradation. In

358 addition to this, centrifugation used to sample the pellet for the degradation experiment

359 concentrates $\mathrm{OM}$ in general and not only diatoms. Thus, there was no possible interpretation

360 of the kinetics of degradation of external saturated FA. On the opposite, unsaturated FA that 361 dominated the FA in the diatom Thalassiosira weissflogii (50.7 $\pm 6.5 \%$ of Total FA ) (Table 1 )

362 are often used as markers of fresh diatom material (Balzano et al., 2011; Najdek et al., 2002).

363 They were proportionally less concentrated in the "degradation culture" (Table 2). However, 364 their decay over time (from $68.5 \pm 27.5 \mu \mathrm{mol} \mathrm{C} .1^{-1}$ to $26.7 \pm 10.2 \mu \mathrm{mol} \mathrm{C} .1^{-1}$ between days 0 365 and 30) (Fig. 7) and that of their individual components (Fig. 8) that characterized the algae in 366 both the WC and external fractions, namely C16:1n7, C16:2n4, C16:3n4, C18:1n7, C18:1n9, 367 C20:5n3 and C22:6n3 (Fig. 4), also reflected the prokaryotic degradation of the algal lipids. At the beginning of the degradation experiment, saturated FA, 14:0, 16:0 and 18:0, 369 constituted the major part of the 'frustule-associated' FA ( $92.5 \%$ of the total FA), as seen in 370 the diatom cultures (Fig. 3). The concentration of the frustule-associated saturated FA 14:0 371 and 16:0 did not exhibit significant differences over time (Fig. 9), whereas the concentration 372 of 18:0 decreased significantly after day 12 (Mann-Whitney $U$ test, $p<0.05$ ). This finding 373 suggested a different association with silica phases of the 18:0 compared to the 14:0 and 16:0. 374 Possibly, 18:0 was associated with a more soluble silica phase, the dissolution of this phase 375 being then necessary for 18:0 to be bioavailable. Unsaturated FA such as hexadecenoic acid $376 \quad 16: 1$ and oleic acid (18:1(n-9)) were still present in the frustule of $T$. weissflogii at the end of 377 incubation. More generally, these results were in line with a protective effect of the frustule 378 on its associated lipid fraction. 


\section{Discussion}

\subsection{Evidence for frustule-associated fatty acids in Thalassiosira weissflogii}

381

The FA composition of Thalassiosira weissflogii was similar to that reported in the literature for diatoms, with a predominance of 16:0, 16:1(n-7) and 20:5(n-3), which are often used as diatom markers (Dalsgaard et al., 2003) (Table 1). The proportions of saturated FA (approximately $35 \%$ ) were comparable to those found in the same species. Only few composition differences existed compared to results on the same species from Klein Breteler et al. (2005), with respect to unsaturated FA, especially the proportions of 16:1(n-7) and 20:5(n-3). This may come from differences in growth conditions (detailed in Table 1) known to impact physiological status and biochemical pools (Coombs et al., 1967; Vrieling et al., 1999).

In addition to these cellular lipids, our study showed that a significant pool of FA inaccessible to conventional lipid extraction technics was associated to the frustule of the diatom Thalassiosira weissflogii. It is now well established that existing interactions between the silica frustule and the organic matter depends on the diatom freshness or at the opposite of their burial period up to their fossilization in sediments. Breaking these interactions requires the use of either strong acids or oxidizing agents, either solvent. Depending on objectives, some protocols are adapted to the study of the silica content of the frustule and aim at denaturing and removing all organic material that it contains (Kamatani, 1971; Loucaides et al., 2008), others require the removal of silica to release organic matter (Bridoux and Ingalls, 2010; Ingalls et al 2003; Kröger et al 1994). In the latter case, the difficulty lies in preserving the integrity of the molecular structures after treatment of the sample. Recently, Morales et al. 2013 proposed a successful protocol to clean fresh diatoms for isotopic analysis of diatom 
403 frustule-bound nitrogen. However, the harsh oxidative treatment transformed all organic 404 nitrogen into nitrates preventing analysis of biochemical groups and molecular structures. To our knowledge the first characterisation of a lipid pool embedded into the frustules of T. weissflogii was done by using nuclear magnetic resonance on SDS/EDTA $/ \mathrm{H}_{2} \mathrm{O}_{2}$ extracted frustules of T. pseudonana by Tesson et al. (2008). Their results indicated the 408 presence of $\mathrm{C}=\mathrm{C}$ from double bonds, $-\left(\mathrm{CH}_{\mathrm{n}}\right)$ - from aliphatic chains and $\mathrm{C}=\mathrm{O}$ from carbonyl 409 groups of FA. Previously, Kates and Volcani (1968) were the first to strongly demonstrate a lipid/frustule association in seven marine diatom species and to analyse FA. These authors washed frustules using distilled water and they added, after a Bligh and Dyer lipid extraction, a methanolic-HCl step to cleave bound-lipids. As such, the cell wall lipid composition was 413 likely dominated by cellular material together with externally bound-lipids as no silica 414 dissolution step was included in the protocol, as shown by our experiment in which fatty acid 415 composition of external fraction was mainly identical to the fatty acid composition of the 416 whole cell. In our study, we pushed a step further the protocol of Kate and Volcani by adding an 418 hot $\mathrm{NaOH}$ silica dissolution step after the first B\&D extraction of washed fragmented diatom 419 pellets. Briefly, in our protocol, frustule pellets were isolated from the cellular material by 420 sequential washings and centrifugation of fragmented diatoms in pure water followed by a B\&D extraction of external lipids. Then, silica frustules were dissolved with $\mathrm{NaOH}\left(1 \mathrm{~mol} .1^{-1}\right)$ and re-extracted at acidic $\mathrm{pH}$ by dichloromethane solvent to obtain the frustule-associated 423 lipids.

Long chain carboxylic acids are major constituents of diatom lipids. They are free or 425 esterified to glycerol, to other alcohols, or to more complex glycosidic and phosphatidic 426 moieties. After sonication and water washing treatments, a fraction of the cellular lipids 427 remained attached to the silica frustule through either hydrogen bonding, or electrostatic and 
428 hydrophobic interactions with other molecules constitutive of the cell wall. This was 429 confirmed by the flow cytometry analysis of frustule pellets showing chla after cells 430 fragmentation and washings.

431 The B\&D protocol was particularly suitable to remove the lipid external fraction with 432 preservation of intact molecular structures. The monophasic solvent extraction mixture 433 (chloroform/methanol/ $0.1 \mathrm{M} \mathrm{NaCl}$ in water) is a powerful extracting agent for both disruption 434 of these bonding's and lipid dissolution (Kates, 1986), while the second step through addition of proper amounts of chloroform and water, achieves an efficient separation of hydrophobic and hydrophilic compounds by changing the monophasic mixture into biphasic. The $\mathrm{NaOH}$ treatment of frustules free from the external organic material gives access to the organic matter associated to the silica matrix. Not only $\mathrm{NaOH}$ increases silica dissolution but it is widely use to cleave hydrogen and covalent bonds, which favour separation of FA from the silica phase and most probably from the organic matrix that may be present. We did not use oxidizing agent such as perchloric acid suitable for the extraction of aqueous metabolites (Ingalls et al. 2009) as it has a deleterious effect on lipid components. We tested the use of HF 443 to dissolve silica but precautions required for its use (plastic or polypropylene containers) 444 makes its use incompatible with the analysis of lipids.

The efficiency of our protocol for isolating and extracting frustule-associated lipids 446 was demonstrated first by the absence of cellular compounds (i. e. phytol and sterols) in 447 frustule-associated lipids, secondly by the fact that the internal standard (19:0) added to the 448 cellular fraction was not recovered with the frustule-associated lipid fraction (see section 2.4) 449 and finally, because FA markers of prokaryotes that contributed for a few percent of the 450 pellets total carbon were also absent from the frustule-associated lipids. In addition, we used 451 our isolation/extraction protocol at different stages of dissolution of the silica phases during a 452 bacterial degradation experiment of these diatoms. Frustule-associated FA thus extracted were 
453 found similar to that of frustule-associated FA in fresh Thalassiosira weissflogii diatom 454 culture validating our protocole and showing little accessibility of these FA to degradation. External FA were identified as cellular lipids because of their composition similar to that of FA in whole cells. While results did not show any specific FA marker of the frustule, frustule-associated FA were characterised by a very low degree of unsaturation with predominance of 14:0, 16:0 and 18:0 FA. Although high $\mathrm{pH}\left(\mathrm{NaOH} 1 \mathrm{~mol}^{-1} \mathrm{I}^{-1}\right)$ and the absence of chlorophyll favour neither autoxidation nor photooxidation (Petit et al., 2013; Rontani, 2001), the reactivity of unsaturated FA to oxidation could have led to a decrease of unsaturation degree due to experimental conditions and extraction process. However, tests to determine the effect of temperature $\left(70^{\circ} \mathrm{C}\right)$ on polyunsaturated FA $(20: 4(\mathrm{n}-6))$, and previous observations that report unsaturated FA conservation during hot saponification $\left(>100{ }^{\circ} \mathrm{C}\right.$, see section 2.7.1), suggest that our protocol had little effect on FA unsaturation. Oleic acid $(18: 1(\mathrm{n}-9))$ and the unidentified 16:1 FA were present in the 'frustule-associated' fraction isolated from $T$. weissflogii cultures, even after 30 days of degradation. Thus, 16:1 and 18:1 FA may likely be associated to a resistant to degradation/dissolution phase of organic or silica matrices.

The very strong similarity between FA profiles of frustules of the different cultures

470 (Fig. 5), although clear differences appeared for others fractions, indicated that 'frustule471 associated' FA were less sensitive to growth conditions than cellular FA. Nevertheless, the 472 study of Soler et al. (2010) shows an effect of nutrient starvations, especially phosphorus 473 starvation, on the FTIR- analysed biochemical composition of $T$. weissflogii frustule. These 474 authors suggested that biochemical changes lead to frustule structure changes leading in fine to changes in $\mathrm{bSiO}_{2}$ dissolution. Therefore, although frustule-associated $\mathrm{FA}$ in sediments may 476 not be used as markers of nutrient regime during paleoproduction, changes in other 477 biochemical fractions should be considered when studying frustules in deep sediments. 
Kates and Volcani (1968) suggested that lipids could be distributed according to their unsaturation level in the frustule. The degradation of the 18:0 and some unsaturated FA (16:1(n-7), 18:2(n-6), 20:4(n-6) and 20:5(n-3)) of the frustule while 14:0 and 16:0 were almost not degraded at all is in agreement with a non-homogenous association of FA with the frustule. These results also confirm the existence of different organic pools in the silica matrix of the frustules (Abramson et al., 2009; Tesson et al. 2008, 2013) and of different silica phases associated with different pool of organic matter (Moriceau et al., 2009). Using a spectroscopic method, Abramson et al. (2009) concluded that the OM encased within the structure of the frustule, which is resistant to different chemical attacks, may be protected from decomposition until the release of this matter into the surrounding environment occurs. This last method advantageously allowed locating the organic pools in Cylindrotheca fusiformis because of its thin frustule. However it is not valid to accurately quantify organic pools and it can hardly be adapted to other species as thicker frustules absorb X-rays too strongly. In contrast, our methodology may be used to quantify the pool of FA embedded in the frustule of a large choice of diatom species.

\subsection{Implications for the export of organic matter}

In some cases, huge numbers of fresh diatom cells can sink out of the euphotic layer (Martin et al., 2011), carrying with them different pool of organic matter; extra-, intra-cellular and intra-frustule. On the contrary to what was previously thought, the fraction of organic matter embedded or associated to the frustule could be an important fraction of the total POC ( $1.8 \%$ of the diatom POC in surface water and up to $5.8 \%$ of the diatom POC after 30 days of degradation).

To better understand the implication of this result in term of export, we compared our experimental data to the in situ data compiled by Ragueneau et al. (2002). More precisely, 
data from the Northern Antarctic Circumpolar Current site (NACC) were used for comparison because $\mathrm{bSiO}_{2}$ dissolution at this site ( $82 \%$ of $\mathrm{bSiO}_{2}$ dissolution at $4224 \mathrm{~m}$ depth) was comparable to the final dissolution measured in our degradation/dissolution experiment $(78 \%$ of our initial $\mathrm{bSiO}_{2}$ after 30 days incubation). The 'frustule-associated' FA represented $5.8 \%$ of the total POC at the end of our experiment. The amount of these 'frustule-associated' FA for each mol of $\mathrm{bSiO}_{2}$ after $78 \%$ of dissolution was 0.23 molC FA.mol bSiO${ }_{2}^{-1}$. Assuming that 14:0 and 16:0 FA are associated to the less soluble phase of the frustule without excluding possible association with the organic matrix, the flux of the 'frustule-associated' FA at $4224 \mathrm{~m}$ may be estimated from the $\mathrm{bSiO}_{2}$ flux $\left(0.14 \mathrm{~mol} \cdot \mathrm{m}^{-2} \cdot \mathrm{yr}^{-1}\right)$ found at this site. This calculated 'frustule-associated' FA flux amounted to $0.0322 \mathrm{molC} . \mathrm{m}^{-2} \cdot \mathrm{yr}^{-1}$ which represents 64 $\%$ of the POC flux at $4224 \mathrm{~m}$ at NACC site. When $\mathrm{N}$ in frustules is on the order of $15 \mu \mathrm{mol}$ $\mathrm{N} / \mathrm{g}$ opal and the $\mathrm{C}$ associated with amino acids is also reported in units of $\mu \mathrm{mol} \mathrm{C/g}$ (Ingalls et al., 2010), this calculation suggests that our protocol extracts frustule-bound fatty acids and another FA fraction not embedded but strongly associated to the frustule and the organic matrix.

Keeping in mind the limitation of this comparison, especially in terms of the species studied (low latitude widespread species) and experimental conditions that did not consider in situ conditions (temperature, pressure, grazing) our study still raises the possible importance of the contribution of 'frustule-associated' FA to the organic carbon flux. According to our simple calculation, these 'frustule-associated' FA could represent an important part of the POC reaching the sediment. Interestingly, this assessment is in line with the correlation observed at depth between the sedimentation flux of POC and the sedimentation flux of $\mathrm{bSiO}_{2}$ as revealed by the study of Armstrong et al. (2009, 2002), Francois et al. (2002), Klaas and Archer (2002) and Ragueneau et al. (2006). 
In further studies of sinking particles and sediments, a more systematic

hydrolysis/dissolution of deep samples should be used to consider this intra-frustule organic matter and to correctly estimate the sedimentation of the different organic pools. Until now, the different protocol used showed that this fraction is taken into account when measuring total POC but not when characterizing the different organic pools. As such, this fraction could be part of the large uncharacterized organic matter pool at depths (Wakeham, 1995). As shown by our degradation/dissolution results, the 'frustule-associated' organic matter is not available to prokaryotes before the complete frustule dissolution. As a result and because of the saturation in dissolved silicon in interstitial water in bottom sediments (Van Cappellen, 2002), its release in sediments should be slower than previously thought and could not be a valuable source of energy for the organisms feeding on the seafloor. Another point of interest is the better preservation of lipids in sediments and their usefulness as biomarkers in paleoceanographic studies (Wakeham, 1995). The fact that sterols are not found embedded in the frustule of $T$. weissflogii, although many deep sediment analysis reveal their presence (Wakeham et al., 1997), could be used to estimate the proportion of intracellular versus 'frustule-associated' organic carbon in opal dominated sediments.

\section{Conclusion}

Our study suggests an interesting and effective protocol to approach the FA composition of the organic matter embedded in or strongly associated to the frustule. Clear differences exist between the FA composition of the whole cell and the FA composition of the OM embedded and associated to the frustule which are characterised by a very low degree of unsaturation. Moreover, FA composition of the whole cell seem a lot more sensitive to small differences in the growth conditions than FA associated to the frustule. When $T$. weissflogii underwent a 30 days degradation, the FA associated to the frustule represented $5.8 \%$ of the remaining POC suggesting the importance of their role in carbon export. With our study we 
infer that organic matter associated to the frustule or embedded in the frustule may be consider when investigating carbon export. This pool could partially explain the correlation observed at depth between $\mathrm{Si}$ and $\mathrm{C}$ sedimentation fluxes despite the decoupling between $\mathrm{bSiO}_{2}$ dissolution and POC degradation processes.

\section{Acknowledgments}

We thank Daniel Delmas from Ifremer-Brest for prokaryote counting during the degradation experiment. We also thank Chantal Bezac for SEM micrography. The authors are grateful to two anonymous reviewers who greatly help improving the manuscript. Flow cytometry analyses were performed with the PRECYM platform (http://www.com.univmrs.fr/PRECYM/) with the help of Aude Barani. This work was supported by the UTIL project of the LEFE/CYBER program of CNRS/INSU. MS was supported by a Ph.D grant from Aix-Marseille University.

\section{References}

Abramson, L., Wirick, S., Lee, C., Jacobsen, C.J., Brandes, J.A., 2009. The use of soft X-ray spectromicroscopy to investigate the distribution and composition of organic matter in a diatom frustule and a biomimetic analog. Deep Sea Research Part II - Topical Studies in Oceanography 56, 1369-1380.

Armstrong, R.A., Lee, C., Hedges, J.I., Honjo, S., Wakeham, S.G., 2002. A new, mechanistic model for organic carbon fluxes in the ocean based on the quantitative association of POC with ballast minerals. Deep Sea Research Part II - Topical Studies in Oceanography 49, 219-236.

Armstrong, R.A., Peterson, M.L., Lee, C., Wakeham, S.G., 2009. Settling velocity spectra and the ballast ratio hypothesis. Deep Sea Research Part II: Topical Studies in Oceanography $56,1470-1478$.

Balzano, S., Pancost, R.D., Lloyd, J.R., Statham, P.J., 2011. Changes in fatty acid composition in degrading algal aggregates. Marine Chemistry 124, 2-13.

Bidle, K.D., Azam, F., 1999. Accelerated dissolution of diatom silica by marine bacterial assemblages. Nature 397, 508-512. 
Bridoux, M.C., Annenkov, V. V, Keil, R.G., Ingalls, A.E., 2012. Widespread distribution and molecular diversity of diatom frustule bound aliphatic long chain polyamines (LCPAs) in marine sediments. Organic Geochemistry 48, 9-20.

Bridoux, M.C., Ingalls, A.E., 2010. Structural identification of long-chain polyamines associated with diatom biosilica in a Southern Ocean sediment core. Geochimica et Cosmochimica Acta 74, 4044-4057.

Brunner, E., Gröger, C., Lutz, K., Richthammer, P., Spinde, K., Sumper, M., 2009. Analytical studies of silica biomineralization: towards an understanding of silica processing by diatoms. Applied Microbiology and Biotechnology 84, 607-16.

Buesseler, K.O., 1998. The decoupling of production and particulate export in the surface ocean. Global Biogeochemical Cycles 12, 297-310.

Chen, X., Wakeham, S.G., Fisher, N.S., 2011. Influence of iron on fatty acid and sterol composition of marine phytoplankton and copepod consumers. Limnology and Oceanography 56, 716-724.

Chiovitti, A., Harper, R.E., Willis, A., Bacic, A., Mulvaney, P., Wetherbee, R., 2005. Variations in the substituted 3-linked mannans closely associated with the silicified walls of diatoms. Journal of Phycology 41, 1154-1161.

Christian, H., 2010. fpc: Flexible procedures for clustering. R package version 2.0-2. http://CRAN.R-project.org/package=fpc.

Coombs, J., Darley, W.M., Holm-Hansen, O., Volcani, B.E., 1967. Studies on the biochemistry and fine structure of silica shell formation in diatoms. Chemical composition of Navicula pelliculosa during silicon-starvation synchrony. Plant Physiology 42, 1601-6.

Dalsgaard, J., St John, M.A., Kattner, G., Müller-Navarra, D., Hagen, W., 2003. Fatty acid trophic markers in the pelagic marine environment. Advances in Marine Biology 46, $225-340$.

Falkowski, P.G., Barber, R.T., Smetacek, V., 1998. Biogeochemical controls and feedbacks

De La Rocha, C.L., Passow, U., 2007. Factors influencing the sinking of POC and the efficiency of the biological carbon pump. Deep Sea Research Part II - Topical Studies in Oceanography 54, 639-658.

Fileman, T.W., Pond, D.W., Barlow, R.G., Mantoura, R.F.C., 1998. Vertical profiles of

François, R., Honjo, S., Krishfield, R., Manganini, S., 2002. Factors controlling the flux of pigments, fatty acids and amino acids: Evidence for undegraded diatomaceous material sedimenting to the deep ocean in the Bellingshausen Sea, Antarctica. Deep Sea Research Part I - Oceanographic Research Papers 45, 333-346. organic carbon to the bathypelagic zone of the ocean. Global Biogeochemical Cycles 16, 1087. 
Gordon, L.I., Jennings, J.C., Ross, A.A., Krest, J.M., 1993. A suggested protocol for continuous flow automated analysis of seawater nutrients (phosphate, nitrate, nitrite and silicic acid) in the WOCE Hydrographic Program and the Joint Global Ocean Fluxes Study. WHP Operations and Methods. WOCE Hydrographic Program Office. Methods manual 19-1.

Goutx, M., Wakeham, S.G., Lee, C., Duflos, M., Guigue, C., Liu, Z., Moriceau, B., Sempéré, R., Tedetti, M., Xue, J., 2007. Composition and degradation of marine particles with different settling velocities in the northwestern Mediterranean Sea. Limnology and Oceanography 52, 1645-1664.

Guillard, R.R.L., Ryther, J.H., 1962. Studies of marine planktonic diatoms : I. Cyclotella nana Hustedt, and Detonula confervacea (Cleve) Gran. Canadian Journal of Microbiology 8, 229-239.

Hedges, J.I., Baldock, J.A., Gélinas, Y., Lee, C., Peterson, M.L., Wakeham, S.G., 2001. Evidence for non-selective preservation of organic matter in sinking marine particles. Nature 409, 801-804.

Hildebrand, M., 2003. Biological processing of nanostructured silica in diatoms. Progress in Organic Coatings 47, 256-266.

Hildebrand, M., 2008. Diatoms, biomineralization processes, and genomics. Chemical reviews $108,4855-74$.

Hildebrand, M., Holton, G., Joy, D.C., Doktycz, M.J., Allison, D.P., 2009. Diverse and conserved nano- and mesoscale structures of diatom silica revealed by atomic force microscopy. Journal of Microscopy 235, 172-87.

Ingalls, A.E., Whitehead, K., Bridoux, M.C., 2010. Tinted windows: The presence of the UV absorbing compounds called mycosporine-like amino acids embedded in the frustules of marine diatoms. Geochimica et Cosmochimica Acta 74, 104-115.

Kamatani, A., 1971. Physical and chemical characteristics of biogenous silica. Marine Biology 95.

Kamatani, A., Riley, J.P., 1979. Rate of dissolution of diatom silica walls in seawater. Marine Biology 55, 29-35.

Kates, M., Volcani, B.E., 1968. Studies on the biochemistry and fine structure of silica shell formation in diatoms. Lipid components of the cell walls. Z. Pflanzenphysiol 19-29.

Klaas, C., Archer, D.E., 2002. Association of sinking organic matter with various types of mineral ballast in the deep sea: Implications for the rain ratio. Global Biogeochemical Cycles 16.

Klein Breteler, W.C.M., Schogt, N., Rampen, S.W., 2005. Effect of diatom nutrient limitation on copepod development: the role of essential lipids. Marine Ecology Progress Series 291, 125-133. 
Kröger, N., Bergsdorf, C., Sumper, M., 1994. A new calcium binding glycoprotein family constitutes a major diatom cell wall component. The EMBO journal 13, 4676-4683.

Kröger, N., Deutzmann, R., Sumper, M., 1999. Polycationic peptides from diatom biosilica that direct silica nanosphere F formation. Science 286, 1129-1132.

Kröger, N., Lehmann, G., Rachel, R., Sumper, M., 1997. Characterization of a 200-kDa diatom protein that is specifically associated with a silica-based substructure of the cell wall. European Journal of Biochemistry 250, 99-105.

Kröger, N., Lorenz, S., Brunner, E., Sumper, M., 2002. Self-assembly of highly phosphorylated silaffins and their function in biosilica morphogenesis. Science 298, 584-6.

Kucki, M., 2009. Biological Photonic Crystals: Diatoms. PhD Thesis. University of Kassel. Department of Natural Science pp 166.

Loucaides, S., Van Cappellen, P., Behrends, T., 2008. Dissolution of biogenic silica from land to ocean: Role of salinity and pH. Limnology and Oceanography 53, 1614-1621.

Mann, D.G., Droop, S.J.M., 1996. 3. Biodiversity, biogeography and conservation of diatoms. Hydrobiologia 336, 19-32.

Martin, P., Lampitt, R.S., Jane Perry, M., Sanders, R., Lee, C., D’Asaro, E., 2011. Export and mesopelagic particle flux during a North Atlantic spring diatom bloom. Deep Sea Research Part I - Oceanographic Research Papers 58, 338-349.

Martin-Jézéquel, V., Hildebrand, M., Brzezinski, M.A., 2000. Silicon metabolism in diatoms : implications for growth. Journal of Phycology 36, 821-840.

Moriceau, B., Goutx, M., Guigue, C., Lee, C., Armstrong, R.A., Duflos, M., Tamburini, C., Charrière, B., Ragueneau, O., 2009. Si-C interactions during degradation of the diatom Skeletonema marinoi. Deep Sea Research Part II - Topical Studies in Oceanography 56, 1381-1395.

Mullin, J.B., Riley, J.P., 1955. The colorimetric determination of silicate with special reference to sea and natural waters. Analytica Chimica Acta 12.

Najdek, M., Debobbis, D., Miokovic, D., Ivancic, I., 2002. Fatty acid and phytoplankton compositions of different types of mucilaginous aggregates in thenorthern Adriatic. Journal of Plankton Research 24, 429-441.

Nelson, D.M., Tréguer, P., Brzezinski, M.A., Leynaert, A., Quéguiner, B., 1995. Production and dissolution of biogenic silica in the ocean : Revised global estimates , comparison with regional data and relationship to biogenic sedimentation. Global Biogeochemical Cycles 9, 359-372.

Patrick, S., Holding, A.J., 1985. The effect of bacteria on the solubilization of silica in diatom frustules. Journal of Applied Microbiology 7-16. 
Petit, M., Sempéré, R., Vaultier, F., Rontani, J.-F., 2013. Photochemical production and behavior of hydroperoxyacids in heterotrophic bacteria attached to senescent phytoplanktonic cells. International Journal of Molecular Sciences 14, 11795-11815.

R Core Team, 2012. R: A language and environment for statistical computing. R Foundation for Statistical Computing, Vienna, Austria.

Ragueneau, O., Dittert, N., Pondaven, P., Tréguer, P., Corrin, L., 2002. Si/C decoupling in the world ocean: is the Southern Ocean different? Deep Sea Research Part II - Topical Studies in Oceanography 49, 3127-3154.

Ragueneau, O., Schultes, S., Bidle, K.D., Claquin, P., Moriceau, B., 2006. Si and C interactions in the world ocean: Importance of ecological processes and implications for the role of diatoms in the biological pump. Global Biogeochemical Cycles 20, 1-15.

Ragueneau, O., Tréguer, P., 1994. Determination of biogenic silica in coastal waters: applicability and limits of the alkaline digestion method. Marine Chemistry 45, 43-51.

Raven, J.A., Waite, A.M., 2004. The evolution of silicification in diatoms: inescapable sinking and sinking as escape? New Phytologist 162, 45-61.

Rontani, J.-F., 2001. Visible light-dependent degradation of lipidic phytoplanktonic components during senescence: a review. Phytochemistry 58, 187-202.

Rontani, J.-F., Zabetti, N., Wakeham, S.G., 2011. Degradation of particulate organic matter in the equatorial Pacific Ocean: Biotic or abiotic? Limnology and Oceanography 56, 333 349.

Soler, C., Claquin, P., Goutx, M., Ragueneau, O., Moriceau, B., 2010. Impact of nutrient starvation on the biochemical composition of the marine diatom Thalassiosira weissflogii: from the whole cell to the frustule fraction. Biogeosciences Discussions 7, 5953-5995.

Tesson, B., Hildebrand, M., 2013. Characterization and localization of insoluble organic matrices associated with diatom cell walls: Insight into their roles during cell wall formation. PloS one 8, e61675.

Tesson, B., Masse, S., Laurent, G., Maquet, J., Livage, J., Martin-Jézéquel, V., Coradin, T., 2008. Contribution of multi-nuclear solid state NMR to the characterization of the Thalassiosira pseudonana diatom cell wall. Analytical and Bioanalytical Chemistry 390, 1889-1898.

Thornton, D.C.O., 2002. Diatom aggregation in the sea: mechanisms and ecological implications. European Journal of Phycology 37, 149-161.

Tréguer, P., Le Corre, P., 1975. Manuel d'analyse des sels nutritifs dans l'eau de mer. Utilisation de l'autoanalyseur II Technicon. Université de Bretagne Occidentale, Brest.

Turner, J.T., 2002. Zooplankton fecal pellets, marine snow and sinking phytoplankton blooms. Aquatic Microbial Ecology 27, 57-102. 
Van Cappellen, P., 2002. Biogenic silica dissolution in the oceans: Reconciling experimental and field-based dissolution rates. Global Biogeochemical Cycles 16.

Volk, T., Hoffert, M.I., 1985. Ocean carbon pumps: Analysis of relative strengths and efficiencies in ocean-driven atmospheric $\mathrm{CO} 2$ changes, in: Sunquist, E.T., Broecker, W.S. (Eds.), The Carbon Cycle and Atmospheric CO2: Natural Variations Archean to Present. American Geophysical Union, Washington, DC, pp. 99-110.

Volkman, J.K., Hallegraeff, G.M., 1988. Lipids in marine diatoms of the genus Thalassiosira : Predominance of 24-methylenecholesterol. Phytochemistry 27, 1389-1394.

Vrieling, E., Poort, L., Beelen, T., 1999. Growth and silica content of the diatoms Thalassiosira weissflogii and Navicula salinarum at different salinities and enrichments with aluminium. European Journal of Phycology 307-316.

Wakeham, S.G., 1995. Lipid biomarkers for heterotrophic alteration of suspended particulate organic matter in oxygenated and anoxic water columns of the ocean. Deep Sea Research Part I - Oceanographic Research Papers 42, 1749-1771.

Wakeham, S.G., Lee, C., Hedges, J.I., Hernes, P.J., Peterson, M.L., 1997. Molecular indicators of diagenetic status in marine organic matter. Geochimica et Cosmochimica Acta 61, 5363-5369. 
genus.

\begin{tabular}{|c|c|c|c|c|c|c|c|c|}
\hline & $\begin{array}{c}T . \\
\text { pseudonana }^{l} \\
\end{array}$ & $\begin{array}{c}\text { T. } \\
\text { pseudonana }^{2 *} \\
\end{array}$ & $\begin{array}{c}T . \\
\text { pseudonana }^{2 \xi}\end{array}$ & $\begin{array}{c}T . \\
\text { oceanica }^{2 *} \\
\end{array}$ & $\begin{array}{c}T . \\
\text { oceanica }^{2 \xi} \\
\end{array}$ & $\begin{array}{c}T . \\
\text { weissflogii }^{3 \alpha} \\
\end{array}$ & $\begin{array}{c}T . \\
\text { weissflogii }^{3 \beta} \\
\end{array}$ & $\begin{array}{c}T . \\
\text { weissflogii }^{4} \\
\end{array}$ \\
\hline \multicolumn{9}{|l|}{ Saturates } \\
\hline $12: 0$ & $\operatorname{Tr}$ & - & - & - & - & - & - & - \\
\hline $14: 0$ & 14.3 & 3.5 & 6.1 & 18.4 & 10.0 & 9.1 & 8.5 & 6.2 \\
\hline $15: 0$ & 0.8 & 0.6 & 1.0 & 1.6 & 1.1 & 1.3 & 1.3 & 0.9 \\
\hline $16: 0$ & 11.2 & 18.4 & 26.9 & 23.0 & 23.7 & 28.3 & 26.4 & 26.4 \\
\hline $17: 0$ & 0.1 & - & - & - & - & - & - & - \\
\hline $18: 0$ & 0.7 & 1.6 & 1.4 & 0.3 & 1.0 & 1.1 & 0.2 & 0.9 \\
\hline $20: 0$ & 0.1 & 1.1 & 0.3 & - & - & - & - & 0.2 \\
\hline $22: 0$ & $\operatorname{Tr}$ & - & - & - & - & - & - & 0.1 \\
\hline $24: 0$ & $\operatorname{Tr}$ & - & - & - & - & 0.1 & 0.1 & 0.1 \\
\hline Sum \% & 27.2 & 25.2 & 35.7 & 43.3 & 35.8 & 39.9 & 36.5 & 34.8 \\
\hline \multicolumn{9}{|l|}{ Mono-UNS } \\
\hline $16: 1(n-13) t$ & 0.4 & $\operatorname{Tr}$ & - & 0.5 & - & $0.4^{\Omega}$ & $0.3^{\Omega}$ & - \\
\hline $16: 1(n-7)$ & 18.0 & 21.0 & 32.0 & 30.0 & 25.8 & 40.5 & 40.8 & 18.3 \\
\hline $16: 1(n-5)$ & 0.3 & 1.6 & $\operatorname{Tr}$ & $\operatorname{Tr}$ & 0.2 & $0.6^{\Omega}$ & $0.7^{\Omega}$ & $0.8^{\varphi}$ \\
\hline $18: 1(n-9)$ & 0.5 & 2.0 & 1.5 & 0.5 & 5.0 & 0.5 & 0.5 & 0.5 \\
\hline $18: 1(n-7)$ & 0.1 & 0.1 & 0.2 & 4.0 & $\operatorname{Tr}$ & 0.2 & 0.1 & 0.6 \\
\hline $20: 1(n-9)$ & 0.2 & - & - & - & - & - & - & $\operatorname{Tr}$ \\
\hline $24: 1$ & - & - & - & - & - & 0.3 & 0.1 & $0.1^{\varphi}$ \\
\hline Sum \% & 19.5 & 24.7 & 33.7 & 35.0 & 31.0 & 41.2 & 41.4 & 20.3 \\
\hline \multicolumn{9}{|l|}{ Poly-UNS } \\
\hline $16: 2(n-7)$ & 2.7 & 1.1 & 1.8 & 0.7 & - & - & - & - \\
\hline $16: 2(n-4)$ & 4.5 & 0.7 & 1.4 & 1.4 & - & - & - & $6.6^{\varphi}$ \\
\hline $16: 3(n-4)$ & 12.7 & 7.1 & 4.8 & 3.5 & 6.4 & $5.8^{\Omega}$ & $6.6^{\Omega}$ & 12.3 \\
\hline $16: 4(n-1)$ & 2.3 & 2.3 & 0.8 & 0.8 & 3.9 & - & - & - \\
\hline $18: 2(n-9)$ & $\operatorname{Tr}$ & - & - & - & - & - & - & - \\
\hline $18: 2(n-6)$ & 0.4 & 1.8 & 1.3 & 1.0 & 1.1 & 0.7 & 0.6 & 0.2 \\
\hline $18: 3(n-6)$ & 0.2 & - & - & - & - & - & - & - \\
\hline $18: 3(n-3)$ & 0.1 & 0.8 & 0.7 & 1.1 & 0.9 & - & - & - \\
\hline $18: 4(n-3)$ & 5.3 & 5.8 & 4.0 & 1.8 & 5.2 & 2.6 & 3.1 & 1.4 \\
\hline $20: 4(n-6)$ & 0.3 & 1.1 & 0.9 & $\operatorname{Tr}$ & $\operatorname{Tr}$ & $\theta$ & $\theta$ & $\operatorname{Tr}$ \\
\hline $20: 4(n-3)$ & 0.3 & - & - & - & - & - & - & - \\
\hline $20: 5(n-3)$ & 19.3 & 23.9 & 12.1 & 11.0 & 13.4 & 7.4 & 9.6 & 22.5 \\
\hline $22: 6(n-3)$ & 3.9 & 3.5 & 1.5 & 1.4 & 0.8 & 0.9 & 0.1 & 1.9 \\
\hline Sum \% & 52.0 & 48.1 & 29.3 & 22.7 & 31.7 & 11.9 & 13.5 & 44.9 \\
\hline other & 1.3 & 2.0 & 1.3 & 0.4 & 1.5 & 0.3 & 0.1 & - \\
\hline Total & 100.0 & 100.0 & 100.0 & 101.4 & 100.0 & 100.1 & 99.1 & 100.0 \\
\hline $\begin{array}{l}749 \\
750 \\
751 \\
752 \\
753 \\
754\end{array}$ & $\begin{array}{l}{ }^{\mathrm{I}} \text { From Volkm } \\
{ }^{2} \text { From Volkm } \\
\text { lifferent species gr } \\
{ }^{\circ} \mathrm{C} \text {. } \\
{ }^{3} \text { From Klein } \\
\left.\text { flogii }{ }^{3 \alpha} \text { and }{ }^{3 \beta}\right) \mathrm{g}\end{array}$ & $\begin{array}{l}\mathrm{n} \text { et al. (1989). C } \\
\mathrm{n} \text { and Hallegraeff } \\
\text { wn in } \mathrm{f} / 2 \text { medium } \\
\text { reteler et al. (2005 } \\
\text { wn on } \mathrm{f} / 2 \text { mediur }\end{array}$ & $\begin{array}{l}\text { ture was made in } \\
\text { 1988). FA were ar } \\
\text { (enriched with Na- } \\
\text { Their results are } \\
\text { and with a } 16 \mathrm{hr} / 8\end{array}$ & $\begin{array}{l}2 \text { medium and } \\
\text { yzed in free } \mathrm{f} \\
\text { DTA for T. oc } \\
\text { esented from } \\
\text { light dark cyc }\end{array}$ & $\begin{array}{l}\text { ith a } 12 \mathrm{hr} / 12 \\
\text { y acids }{ }^{*} \text { and } \mathrm{t} \\
\text { nica) and wit } \\
\text { o separated c } \\
\text { at } 15^{\circ} \mathrm{C} .{ }^{\Omega} \mathrm{D}\end{array}$ & $\begin{array}{l}\text { light/dark cycle } \\
\text { cylglycerols } \\
12 \mathrm{hr} / 12 \mathrm{hr} \text { ligh } \\
\text { tinuous cultures } \\
\text { ble bond positic }\end{array}$ & $\begin{array}{l}20^{\circ} \mathrm{C} \text {. } \\
\text { rately in } \\
\text { ark cycle at } \\
T \text {. } \\
\text { is not }\end{array}$ & \\
\hline
\end{tabular}


indicated for three FA: 16:1, 16:1 and 16:3. For a convenient presentation, we assume their identity according to their contribution. ${ }^{\theta}$ Two FA, 20:4(n-6) and 20:5(n-3), are pooled in their study.

${ }^{4}$ From this study (average of two independent cultures). ${ }^{\varphi}$ In our study, the position of some double bonds are not localized.

$\operatorname{Tr}=\operatorname{Trace}<0.05 \%$ as we assume in Volkman and Hallegraeff (1988). For non detected FA, a - is indicated. UNS $=$ unsaturated. 
Table 2. FA compositions (mol \%) of Thalassiosira weissflogii in this study.

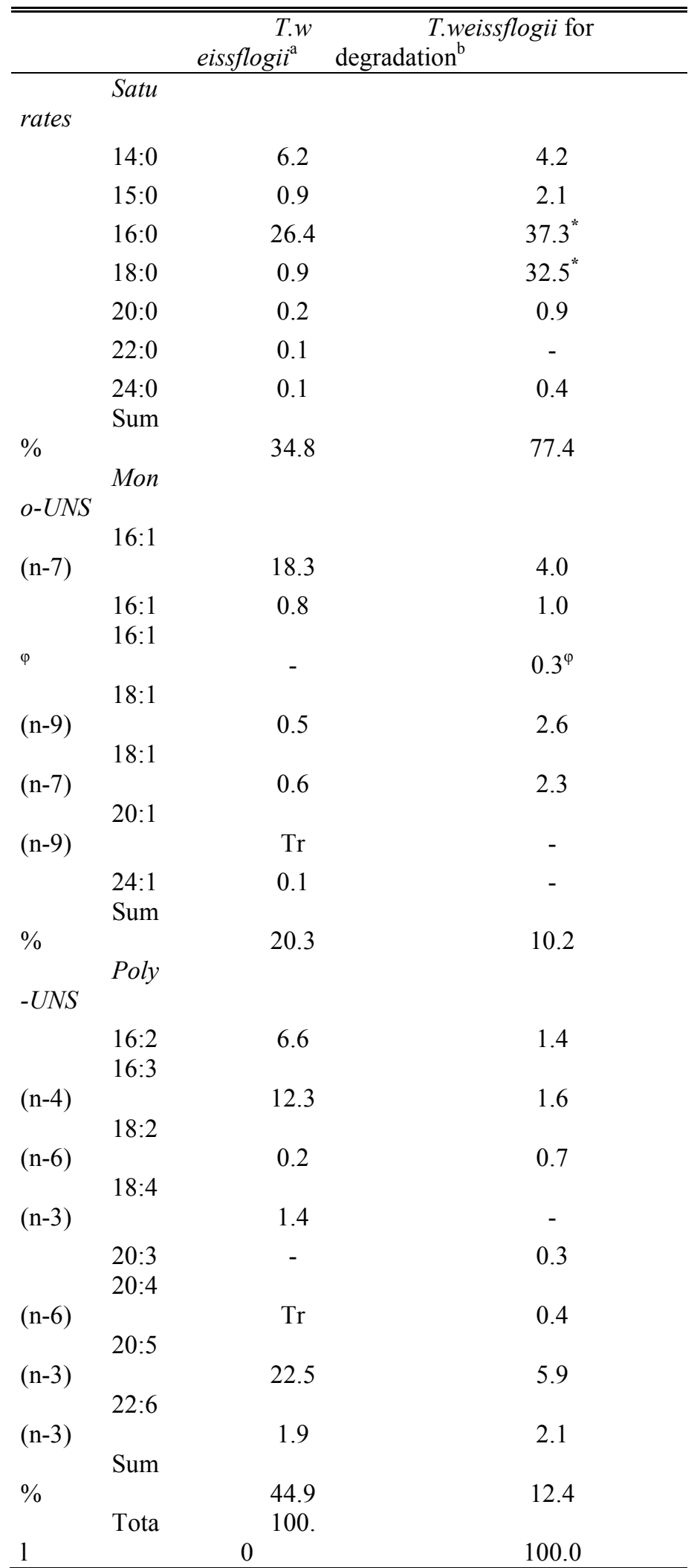

${ }^{a}$ FA composition at the end of the growth phase (average of the two cultures, $n=6$ ).

${ }^{\mathrm{b}} \mathrm{FA}$ composition at the beginning of the degradation experiment $(\mathrm{n}=3)$.

* Some FA bacterial markers were found in lipid extracts from degradation experiment samples (15:0iso, 15:0anteiso and 17:0). We choose to not take them into account and keep the composition found during growth of $T$. weissflogii. However, it is clear that other FA such as palmitic and stearic acids are shared by diatoms and bacteria. ${ }^{\varphi}$ Another 16:1 FA was found in FA profiles but the position of its double bond was not localized. 
Figure 1. Schematic representation showing the different steps of the protocol. Cells

line), total sterols (black diamonds and dashed line) and phytol (grey squares and line) in are broken using hot sonication and centrifuged three times with milli $Q$ water to remove intracellular material. Pellets of fragmented frustules are then extracted using organic solvents following the Bligh and Dyer protocol (B\&D). The organic phase contains the external fraction. Frustules accumulated at the interface form a "white layer" composed of washed frustules (see photo of scanning electron microscopy). Frustules are dissolved with $\mathrm{NaOH} 1 \mathrm{M}$ at $95^{\circ} \mathrm{C}$ to release frustule-associated fraction that is further extracted with $\mathrm{CH}_{2} \mathrm{Cl}_{2}$ at $\mathrm{pH}<2$.

Figure 2. Cytograms of whole cells (A) and isolated frustules after three centrifugations with $40 \mathrm{ml}$ of Milli $Q$ water (B). Cytograms represent the chlorophyll fluorescence of particles function of their granularity (side scatter). Some frustules still show fluorescence of chlorophyll molecules indicating presence of external material.

Figure 3. Frustules fragments of Thalassiosira weissflogii freed from their "external fraction" observed in scanning electron microscopy.

Figure 4. Relative FA compositions of whole cells, external and frustule-associated fractions. All samples are gathered under each bar by averaging the FA contribution in each culture. $n=6$ for whole cells (culture B and C) and $n=9$ for the two other fractions (cultures A, B and C). Error bars represent the standard deviation.

Figure 5. Graphical representation of the classical multidimensional scaling analysis of whole cells samples (black diamonds), external fractions (grey dots) and frustule-associated fractions (white triangles). Confident ellipses containing 50 and $95 \%$ of the data used to build clusters obtained from $k$-means analysis are represented.

Figure 6. Evolution of concentrations of total POC (black dots), bacterial OC (black squares), and biogenic silica ( $\mathrm{bSiO}_{2}$, grey triangles) during the course of the degradation experiment. Solid and dashed lines represent averaged value for each parameter. OC (particulate and bacterial) and $\mathrm{bSiO}_{2}$ concentrations are expressed as $\mu \mathrm{mol.1}{ }^{-1}$. For a convenient representation, the $\mathrm{y}$ axis for $\mathrm{bSiO}_{2}$ concentration is on the right of the graph.

Figure 7. Concentrations $\left(\mu \mathrm{molC} . \mathrm{l}^{-1}\right.$ ) of total unsaturated FA (black dots and solid

external fractions at each sampling day during the course of the degradation experiment. Error bars represent standard deviation $(n=3)$. After day 12, phytol concentrations were under detection limit. At day $18, \mathrm{n}=1$.

Figure 8. Concentrations $\left(\mu \mathrm{molC} \cdot \mathrm{l}^{-1}\right)$ of individual unsaturated FA characteristic of external fractions at each sampling day during the course of the degradation experiment. Error bars represent standard deviation $(\mathrm{n}=3)$. At day 18 and $30, \mathrm{n}=1$.

Figure 9. Mean concentrations ( $\mu$ molC. $1^{-1}$ ) of total FA (dots and solid line), saturated

804 14:0 (triangles and dotted line), 16:0 (diamonds and long-dashed line) and 18:0 (squares and 
809

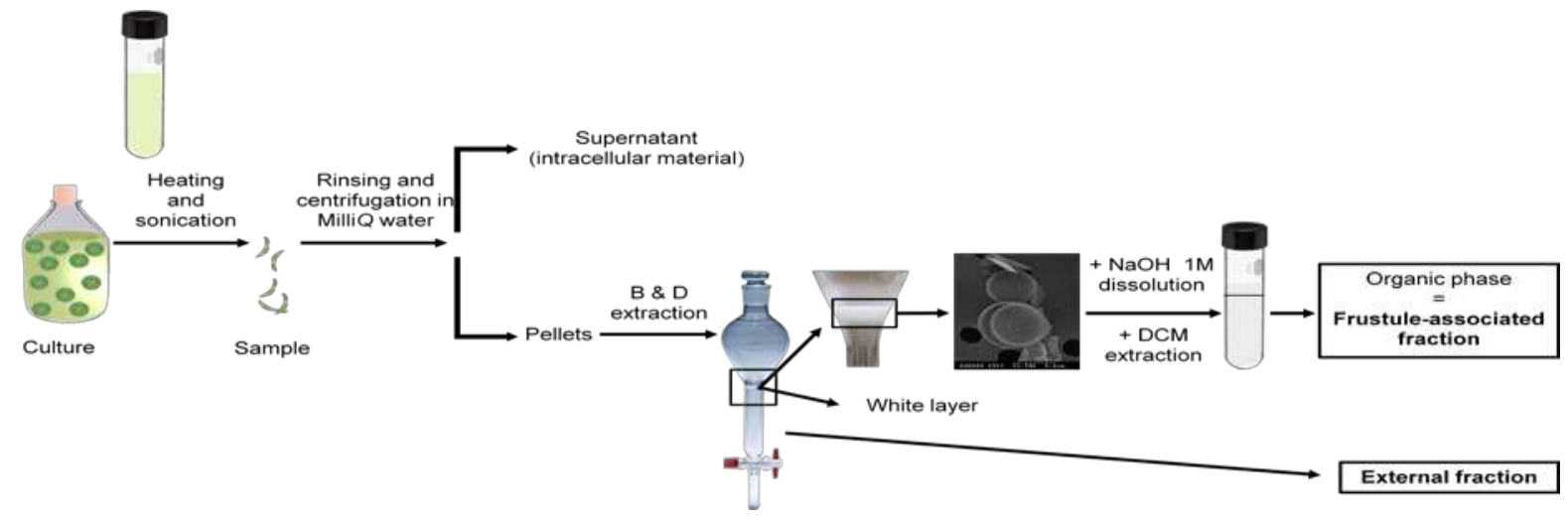

811
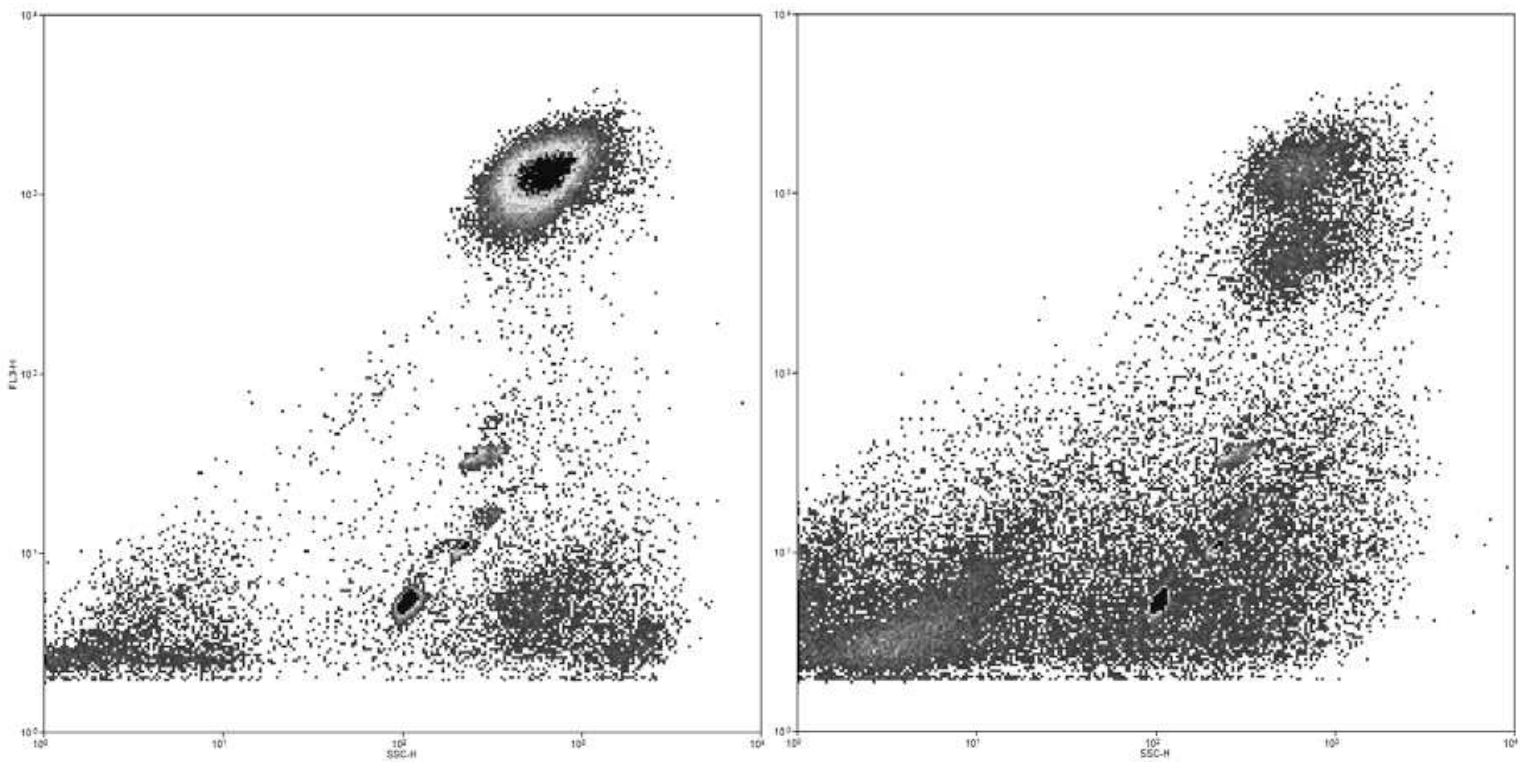

Figure 2. 


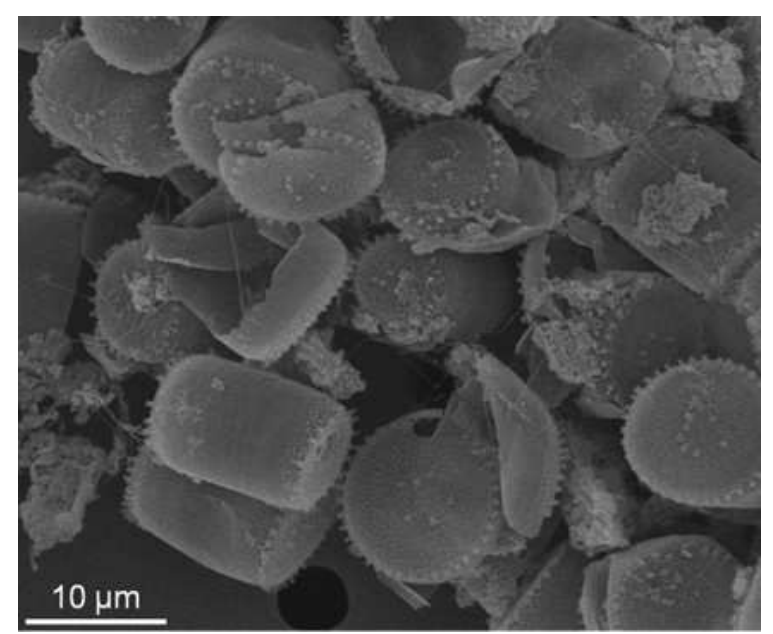

815

Figure 3. 


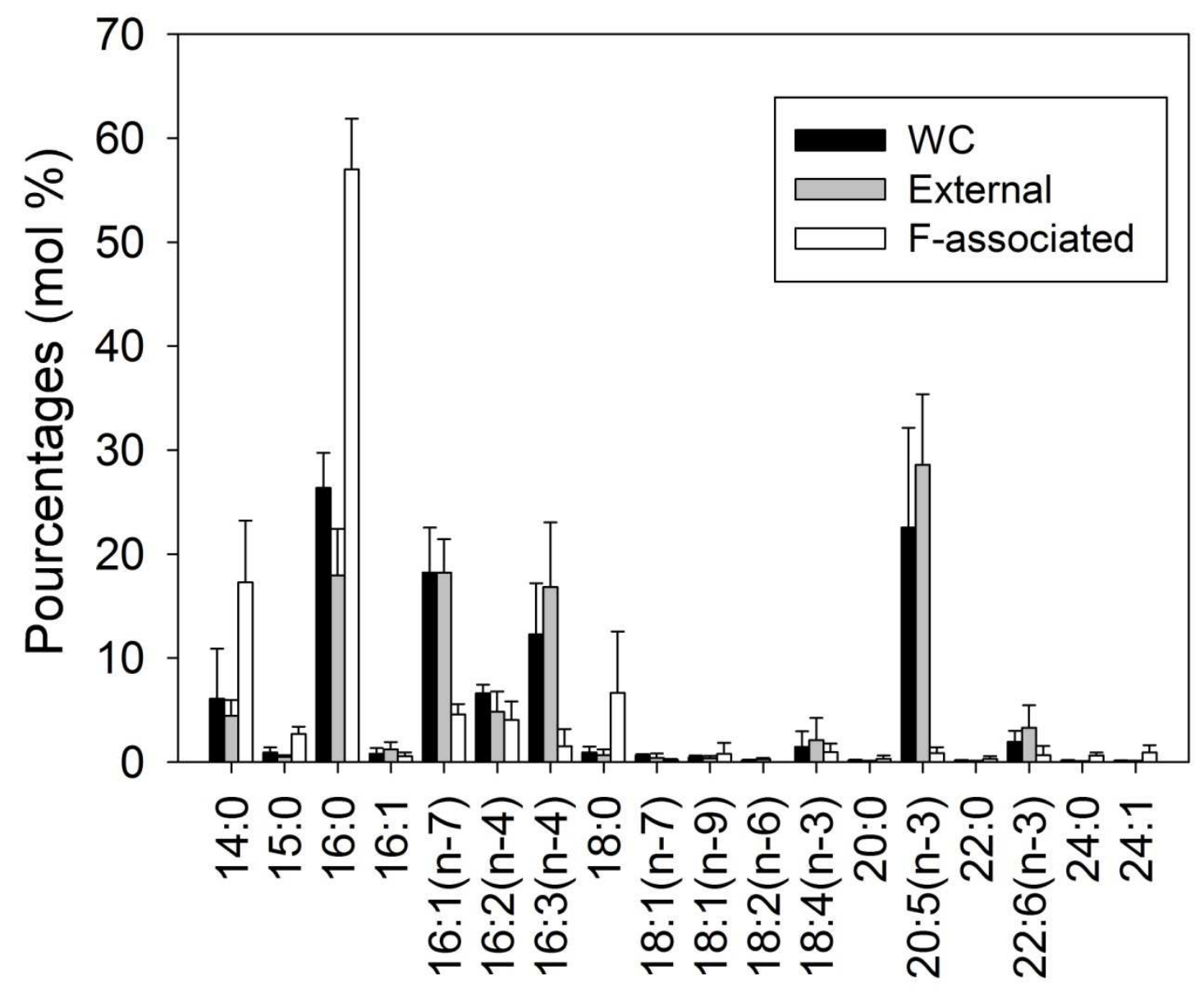

816

Fatty acids

817

Figure 4. 


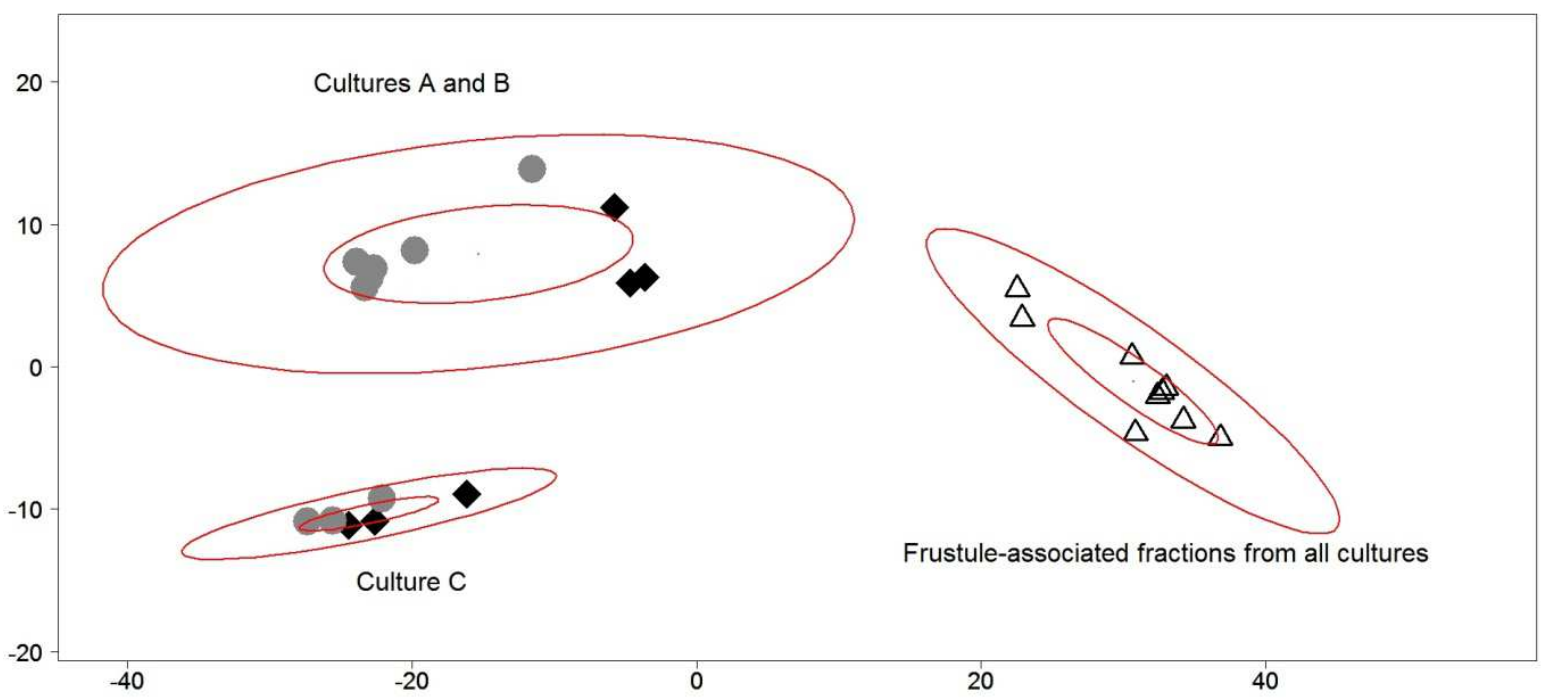

818

Figure 5. 


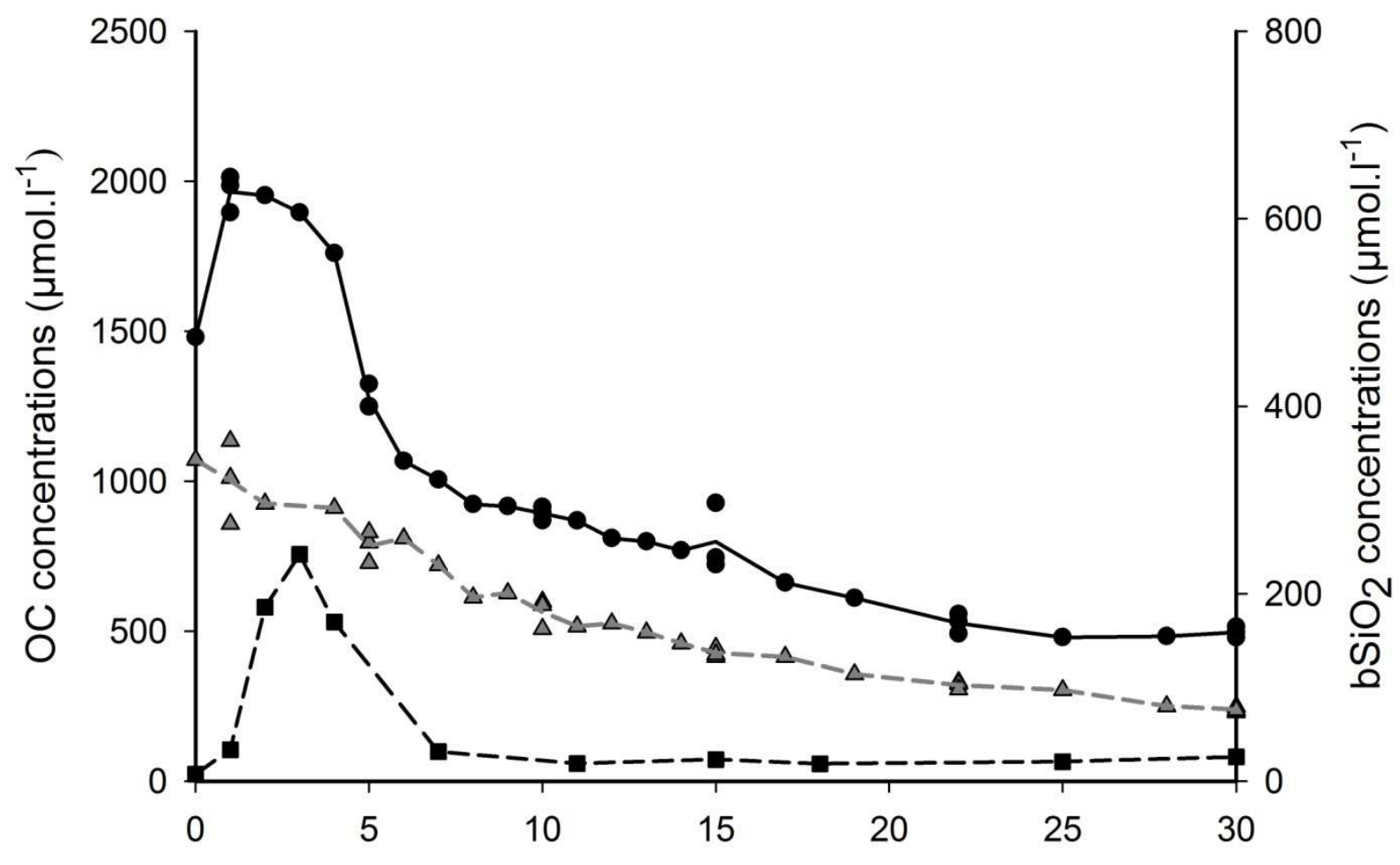

$821 \quad$ Figure 6. 


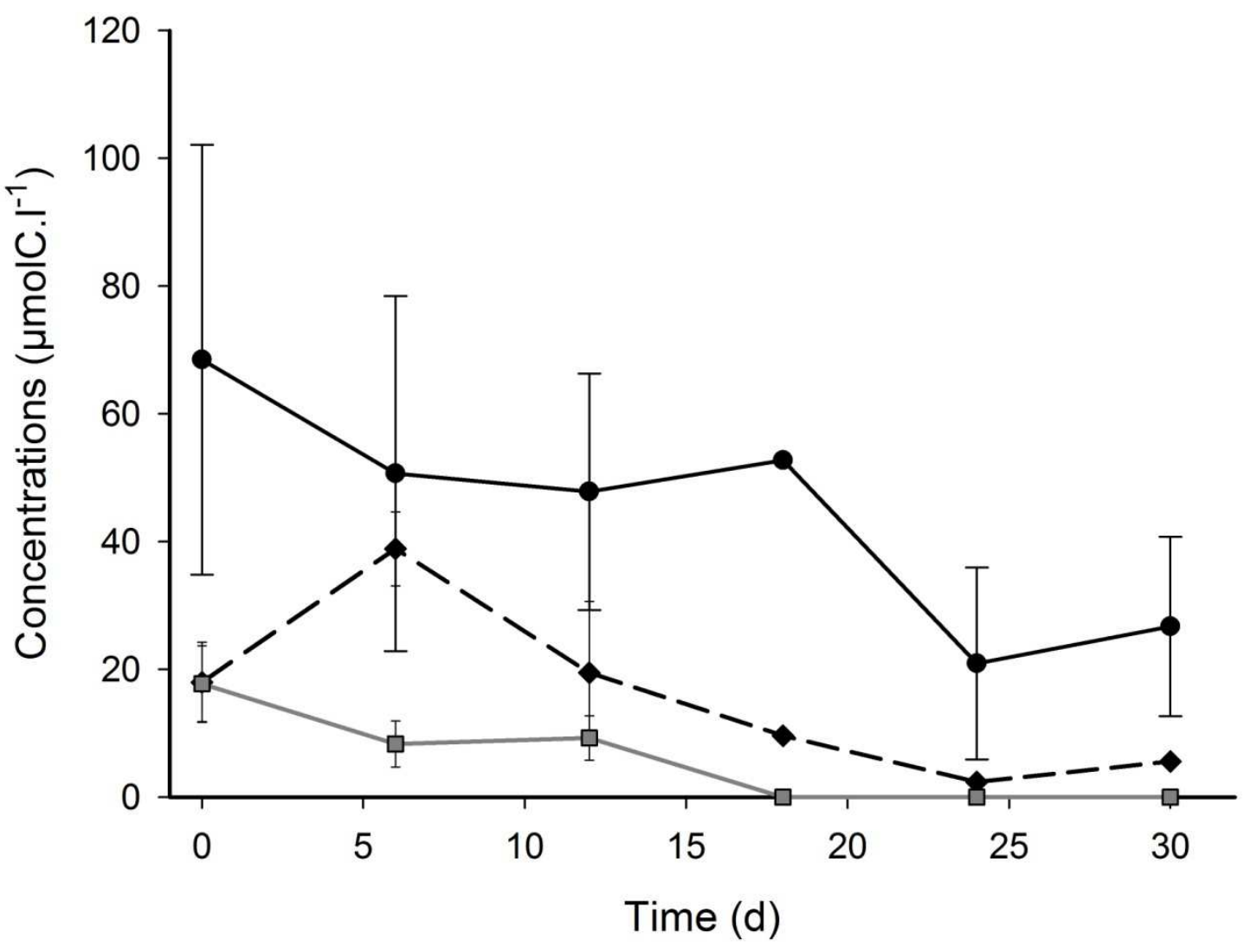

822

823

Figure 7.

824 


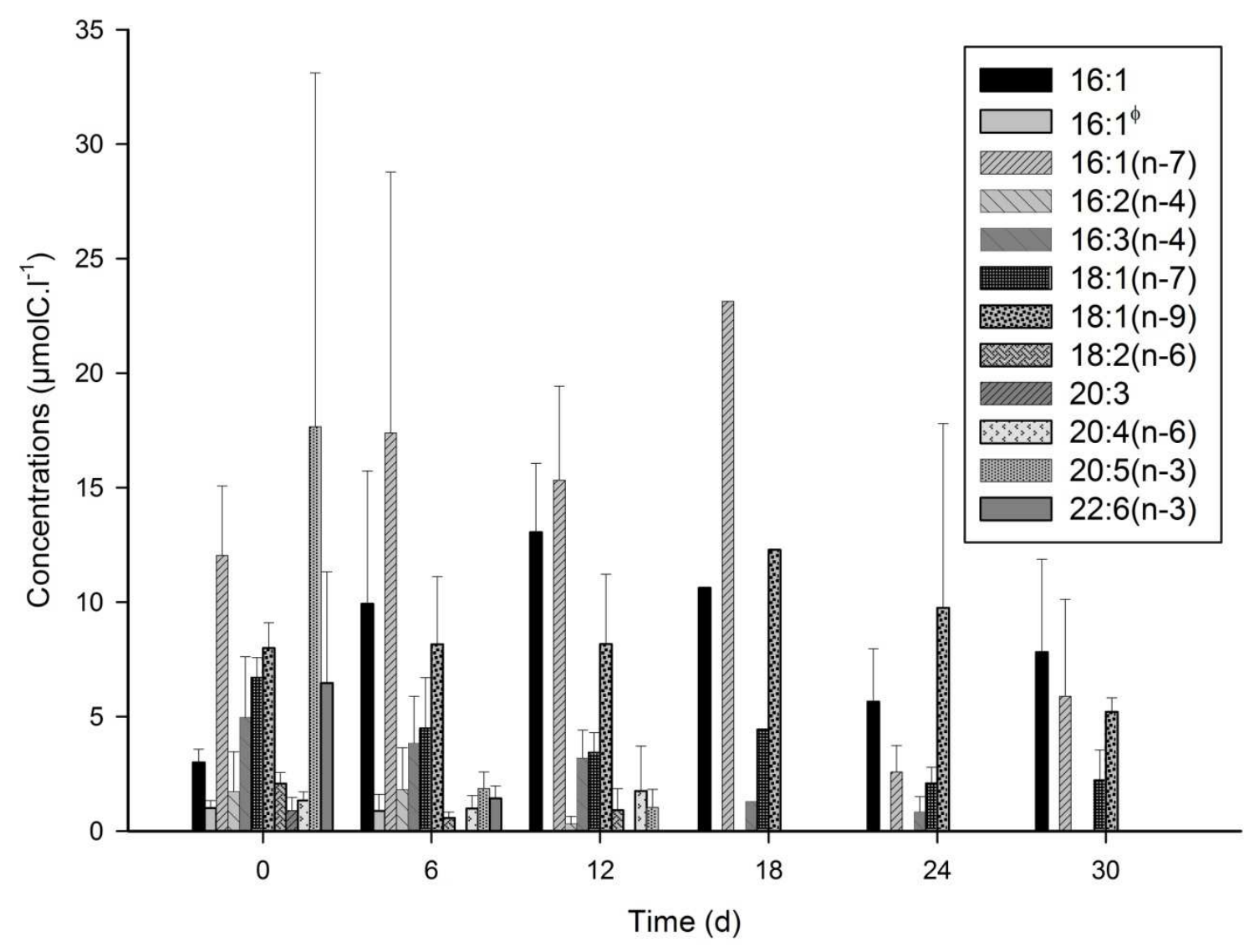

826

Figure 8. 

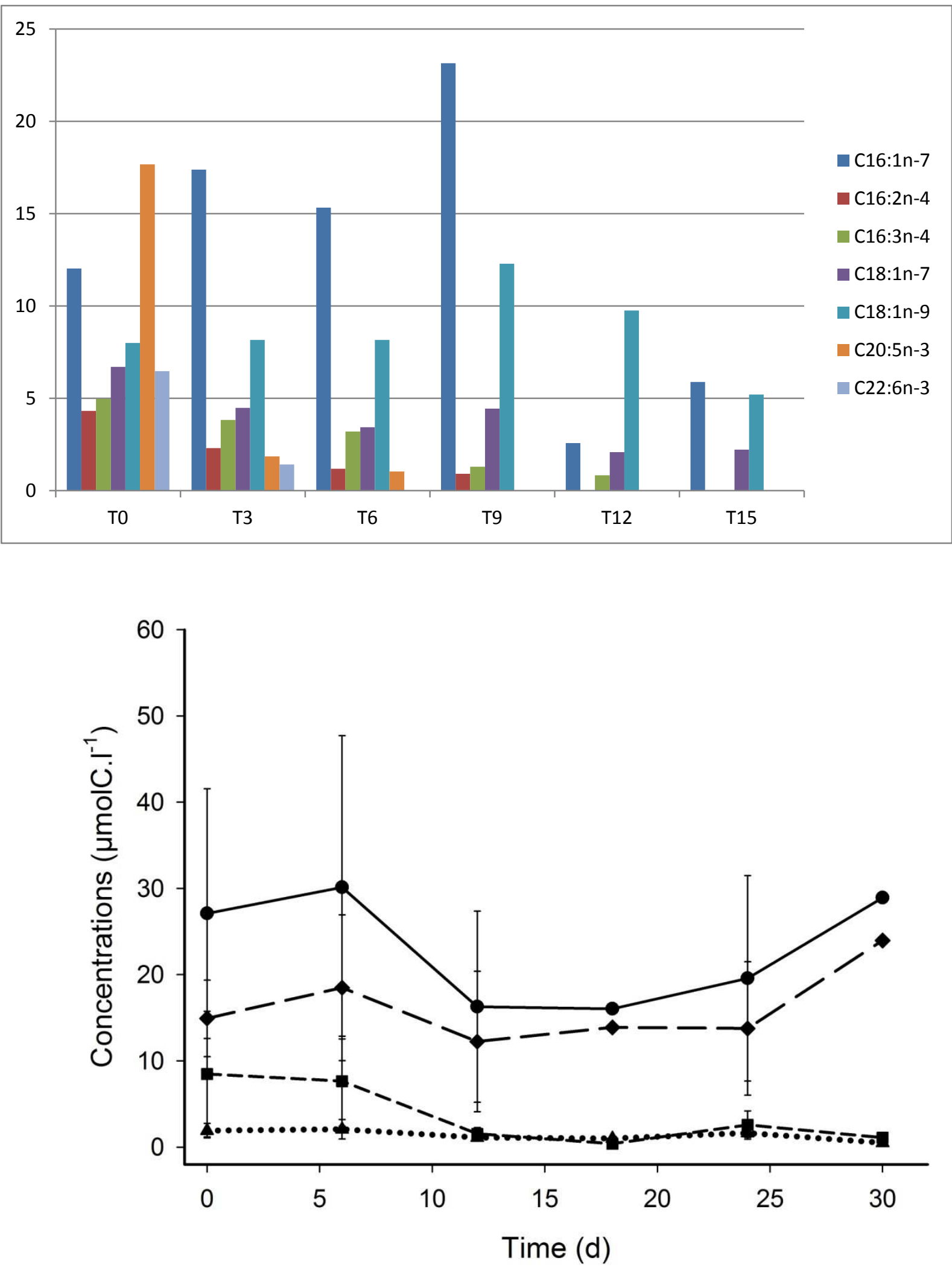

829

Figure 9. 